NBER WORKING PAPER SERIES

\title{
A TARIFF-GROWTH PARADOX? \\ PROTECTION'S IMPACT THE WORLD AROUND 1875-1997
}

\author{
Michael A. Clemens \\ Jeffrey G. Williamson \\ Working Paper 8459 \\ http://www.nber.org/papers/w8459
NATIONAL BUREAU OF ECONOMIC RESEARCH
1050 Massachusetts Avenue
Cambridge, MA 02138
September 2001

We have received superb research assistance from István Zöllei. In addition, we are grateful to many who have helped in our search for country tariff and other data used in this paper: Luis Bertola, John Coatsworth, Bouda Etemad, David Feeny, Aurora Gomez, Paul Gregory, David Hummels, Doug Irwin, Pedro Lains, Peter Lindert, Ian McLean, Anna Maria Mayda, Sevket Pamuk, Dwight Perkins, Gunnar Persson, Leandro Prados, Dani Rodrik, Athanasios Vamvakidis, and Tarik Yousef. We also benefited from conversations with Kevin O'Rourke and Andrew Warner. Remaining errors belong to us. Williamson acknowledges with pleasure financial support from the National Science Foundation SES-0001362, and both authors thank the Center for International Development for allocating office space to the project. The views expressed herein are those of the authors and not necessarily those of the National Bureau of Economic Research.

(C) 2001 by Michael A. Clemens and Jeffrey G. Williamson. All rights reserved. Short sections of text, not to exceed two paragraphs, may be quoted without explicit permission provided that full credit, including $\odot$ notice, is given to the source. 
A Tariff-Growth Paradox? Protection's Impact the World Around 1875-1997

Michael A. Clemens and Jeffrey G. Williamson

NBER Working Paper No. 8459

September 2001

JEL No. F1, N7, O1

\begin{abstract}
$\underline{\text { ABSTRACT }}$
This paper uses a new database to establish two findings covering the first globalization boom before World War I, the second since World War II, and the autarkic interlude in between. First, there is strong evidence supporting a Tariff-Growth Paradox: protection was associated with fast growth before World War II, while it was associated with slow growth thereafter. Second, there is strong evidence supporting regional asymmetry: while the tariff-growth association was powerful and positive in the Core and rich New World before World War II, it was typically weak and negative in the poor Periphery. The paper offers explanations for the Paradox by controlling for a changing world economic environment. It shows how the oft-quoted Sachs-Warner results for 1970-1989 are significantly revised when one controls for trading partners' growth, trading partners' tariffs and the effective distance between them over the longer half-century 1950-1997. Falling partners' tariffs was the most important force accounting for the switch in sign on the tariff-growth connection after 1950. An increase in own tariffs after 1950 hurt growth, but it would not have hurt growth in a world where partners' tariffs were much higher, trading partners' growth much slower, and the world less closely connected by transportation. World environment matters. Leader-country reaction to big world events (like the Great Depression) matter. Followers take notice.
\end{abstract}

Michael A. Clemens

Department of Economics

Harvard University

Cambridge, MA 02138

and Center for International Development mclemens@fas.harvard.edu
Jeffrey G. Williamson

Department of Economics

Harvard University

Cambridge, MA 02138

and NBER and Center for International Development jwilliam@kuznets.harvard.edu 


\section{The Tariff-Growth Connection}

Does protection inhibit growth? While theory may be ambiguous, late $20^{\text {th }}$ century evidence certainly is not. This evidence can be found in four kinds of studies.

First, the authors of a large National Bureau of Economic Research project assessed trade and exchange-control regimes in the 1960s and 1970s by making classic partial-equilibrium calculations of deadweight losses (Bhagwati and Krueger 1973-1976). They concluded that the barriers imposed significant costs in all but one case. However, these standard welfare calculations have been criticized by those who have pointed out that, in such studies, protection is not allowed a chance to lower long-run cost curves, as in the traditional infant-industry case (Baldwin 1969), or to foster industrialization and thus growth, as in those modern growth models where industry is the carrier of technological change and capital deepening. Thus, economists have had to look for more late $20^{\text {th }}$ century proof to support the opennessfosters-growth hypothesis.

Second, analysts have contrasted the growth performance of relatively open with relatively closed economies. The World Bank has conducted such studies for 41 countries going back before the first oil shock. The correlation between trade openness and growth is abundantly clear in these studies (Lindert and Williamson 2001: Table 3), but the analysis is vulnerable to two criticisms. Assigning countries to trade policy categories is always tricky, since it is hard to measure overall openness (Anderson and Neary 1994; Sachs and Warner 1995). More importantly, it is hard to isolate the effect of trade policies alone, since other policies usually change at the same time. Liberalism typically comes as a package. Thus, countries that liberalized their trade also liberalized their domestic factor markets, liberalized their

\footnotetext{
${ }^{1}$ This section relies heavily on the recent survey paper by Peter Lindert and Jeffrey Williamson (2001: pp. 21-25). We choose to focus on growth effects, in the context of a well-developed literature on postwar trade and growth. We are aware, however, of a younger literature on the relationship between trade and levels of wealth (notably in Frankel and Romer 1999, extended back to 1913 by Irwin and Terviö 2001).
} 
domestic commodity markets, and set up better property-rights enforcement. The appearance of these domestic policies may deserve more credit for raising income while the simultaneous appearance of more liberal trade policies may deserve less.

Third, there are country event studies, where the focus is on periods when trade policy regimes change dramatically enough to see their effect on growth. For example, Anne Krueger $(1983,1984)$ looked at trade opening moments in South Korea around 1960, Brazil and Colombia around 1965, and Tunisia around 1970. Growth improved after liberalization in all four cases. More recently, David Dollar and Aart Kraay (2000) examined the reforms and trade liberalizations of 16 countries in the 1980s and 1990s, finding, once again, the positive correlation between freer trade and faster growth. Of course, these reform episodes may have changed more than just global participation, so that an independent trade effect may not have been isolated.

Fourth, macro-econometric analysis has been used in an attempt to resolve the doubts left by simpler historical correlations revealed by the other three kinds of studies. This macro-econometric literature shows that free trade policies have had a positive effect on growth in the late $20^{\text {th }}$ century, especially with many other relevant influences held constant. The most famous of these is by Jeffrey Sachs and Andrew Warner (1995), but many others have also confirmed the openness-fosters-growth hypothesis for the late $20^{\text {th }}$ century (e.g. Dollar 1992; Edwards 1993; Bloom and Williamson 1998; Dollar and Kraay 2000).

\section{The Tariff-Growth Paradox}

If free trade has been good for growth since World War II, why was it bad for growth before? About thirty years ago, Paul Bairoch (1972) argued that protectionist countries grew faster in the $19^{\text {th }}$ century, not slower as every economist has found for the late $20^{\text {th }}$ century. Bairoch's sample was 
European, it looked at pre-1914 experience only, and it invoked unconditional analysis, controlling for no other factors. Like the second group of modern studies listed above, it simply compared growth rates of major European countries in protectionist and free trade episodes. A decade later, Forrest Capie (1983) confirmed the Bairoch result with a pre-1914 European sample of four (Germany, Italy, the UK and Russia), using event analysis. Alfred Eckes (1995) attempted to establish causation from high tariffs to fast growth for $19^{\text {th }}$ century United States, although his work is assiduously criticized by Douglas Irwin (2001). Most recently, Kevin O'Rourke (2000) got the Bairoch finding again, this time using macroeconometric conditional analysis on a ten country sample drawn from the pre-1914 Atlantic economy (Australia, Canada, Denmark, France, Germany, Italy, Norway, Sweden, UK, US). In short, these four scholars were not able to find any evidence before World War I supporting the openness-fosters-growth hypothesis. Another recent study (Vamvakidis 1997) couldn't find any interwar evidence supporting the openness-fosters-growth hypothesis either, although it was (once again) based on a small, mostly OECD sample.

These pioneering historical studies suggest that the Tariff-Growth Paradox should be taken seriously. Was there a regime switch somewhere between the start of World War I and the end of World War II, and, if so, when and why? Nobody has yet performed the test consistently and comprehensively from the mid-19th century to the present, using the same data, the same model, and for a sample that covers the whole world. Table 1 offers such a test for a sample of 35 countries that will be used throughout this paper: 4 members of the industrial Core (France, Germany, UK, US); 7 rich European Offshoots (Argentina, Australia, Canada, Chile, Cuba, New Zealand, Uruguay); 10 from the European Periphery (Austria-Hungary, Denmark, Greece, Italy, Norway, Portugal, Russia, Serbia, Spain, Sweden); and 14 less developed countries (LDCs) in Asia, the Mideast and Latin America (Brazil, Burma, Ceylon, China, Colombia, Egypt, India, Indonesia, Japan, Mexico, Peru, the Philippines, Siam, Turkey). Table 1 uses the average tariff rate as our measure of protection. There is, of course, a well-developed literature 
that debates how to measure openness (e.g., Anderson and Neary 1994; Sachs and Warner 1995; O’Rourke 1997; Anderson 1998). That literature makes it clear that trade share measures must be rejected since they are so obviously endogenous. Among the exogenous policy measures available, the average tariff rate is the easiest to collect.2

The model estimated in Table 1 is of the convergence variety, ${ }_{\text {but }}$ only conditioned by the tariff rate. The tariff rate and GDP per capita level are both measured at year $t$, while the subsequent GDP per capita growth rate is measured over the half decade following. Thus, the last two pre-World War II observations are 1934, which relates to growth between 1934 and 1939, and 1908, which relates to the growth between 1908 and 1913. The two world wars are ignored, and the postwar also reports 1970-1990 to conform with the years studied by Sachs and Warner (1995).

The World War II regime switch and the Tariff-Growth Paradox are both stunningly clear in Table 1. The estimated coefficient on log of the tariff rate is -2.88 for $1950-1998$ and -1.39 for $1970-1990$, both highly significant: thus, tariffs were associated with slow growth after 1950. In contrast, the estimated coefficient is +0.58 for $1865-1908$ and +1.31 for $1919-1934$, again both highly significant: thus, tariffs were associated with fast growth before 1939.

This paper will explore whether the Paradox persisted the world around, or whether instead there was asymmetry between rich industrial economies in the Core and poor agricultural economies in the Periphery. Presumably, the protecting country has to be ready for industrialization, accumulation, and human capital deepening if the long run tariff-induced dynamic effects are to offset the short run gains from trade given up. We test the asymmetry hypothesis by asking whether the Paradox persisted for all

\footnotetext{
${ }^{2}$ The average tariff rate is measured here as customs revenues (import duties only) as a share of total import values. We use the phrase "exogenous tariff policy" here, but we are very aware of the flourishing endogenous tariff literature. Indeed, we plan to use our data base to contribute to that literature in another paper.

${ }^{3}$ But note that the estimation in Table 1 imposes country fixed effects, so that those negative coefficients on log initial GDP per capita do not speak to world divergence ("big time": Pritchett 1997) which took place over most of this century. We will have more to say about this below.
} 
regions, industrial and primary-product producing. The paper will also ask whether the tariff policies of trading partners mattered. Were high tariffs at home matched by high tariffs abroad, and did it matter? Also, did trading partners' GDP growth improve performance at home? It might be argued that conditions were less auspicious for trade liberalization as a means of achieving industrialization before 1940 since there were so few fast-growing export markets for manufactures. A policy of relying on domestic markets empty of foreign competitors might have had more going for it then. The parallel argument today would be that although there are fast-growing world markets for manufactures, there are also so many competitors in those markets that industrial late-comers—like Latin America—suffer, while East Asia benefitted by going open early without many competitors. Historical timing matters, and this fact might help explain the Paradox.

\section{Country Tariff Experience 1865-1950}

Figure 1 plots the worldwide own tariff average, and Figure 2 plots it for the four regional clubs. There are four regions plotted there - Core, European Periphery, Rich European Offshoots and LDCs the country members of which have already been identified above.

The first thing to note is the powerful role played by inflations and deflations in the past. Import duties were typically specific until modern times, quoted as pesos per bale, yen per yard, or dollars per bag. Obviously, abrupt changes in price levels would change import values in the denominator, but not the legislated specific duty in the numerator, thus producing big equivalent ad valorem rate changes, that is big changes in percentage rates. Ad valorem rates are more common today, so that equivalent tariff rates are

\footnotetext{
${ }^{4}$ We also have calculated the regional weighted averages for both Figures 2 and 3, where weights are the country's total export share in regional exports. The text story is not significantly changed, and we prefer to treat countries as independent policy units regardless of size. The complete data base used in this paper is described at length in the Appendix.
} 
less affected by inflation and deflation. ${ }^{\mathrm{G}}$ The impact of inflations during the two world wars were quite spectacular, and they had nothing to do with policy (except status quo ante). Thus, the tariff rates in all four regions fell sharply between 1914 and 1919, and again between 1939 and 1947. Part of the rise in tariffs immediately after World War I was also due to post-war deflation and the partial attainment of prewar price levels. The price deflation after 1929 was even more spectacular, and it too served to raise tariffs rates at least on duties that were still specific (import values now declining). The process repeats during the World War II inflations, but, in contrast, there is no sign of resumption of the very high rates attained in the 1930s.

Second, note in Figure 1 the protectionist drift worldwide between 1865 and World War I, a modest anti-globalization backlash if you will, registering a slow retreat from the liberal pro-global trade positions in mid-century (Williamson 1998).

Third, note too the enormous variance in levels of protection between the regional club averages. There was, of course, even greater variance within these regional clubs. In 1905, tariffs in Uruguay (the most protectionist Rich European Offshoot) were about two and a half times those in Canada (the least). In the same year, tariffs in Brazil and Colombia (the most protectionist LDCs) were almost ten times those in China and India (the least). The same high-low range appeared in the Core (the US five times the UK) and the European Periphery (Russia six times Austria-Hungary). The empirical analysis later in this paper will treat countries as the unit of observation, but for now let's simply look at the regional clubs.

Prior to World War I, tariffs were much higher in the Rich European Offshoots than anywhere else. Furthermore, they would have been even higher had we allocated to this club one of the most-

\footnotetext{
${ }^{5} \mathrm{We}$ are certainly not the first to notice this effect. Douglas Irwin has made the same point in accounting for US tariff experience between the Civil War and the Great Depression where "roughly two-thirds of dutiable U.S. imports were subject to specific or compound duties ..." (Irwin 1998: p. 1017). Although it fell in the $20^{\text {th }}$ century, the share was still half by the mid-1960s. A compound duty refers to one that imposes both specific and ad valorem duties on a given import good.
} 
protectionist, the US (which is allocated instead to the Core). ${ }^{6}$ The European members of the Core (France, Germany, UK) had the lowest tariffs, although the US serves to raise the club average. Much of the LDC club members were colonies of the Core (Burma, Ceylon, Egypt, India, Indonesia, the Philippines), or were forced to sign free trade agreements with the Core since the latter had naval guns trained on their potential trading partners (China, Japan), or viewed nearby gunboats as a sufficient threat to go open on their own (Siam). Thus, the LDC tariff rates are pretty much like those of the Core early on, but they start drifting towards protection in the 1890s, long before the African and Asian independence movement after World War II. This protectionist drift is due to events in poor Latin America (Brazil, Colombia, Mexico) as well as in Egypt, Japan, and Turkey (late Ottoman). In 1865, the LDCs had the lowest tariffs, while in 1914 they were second to the Rich European Offshoots. The European Periphery leaps to high levels of protection after the 1870 s, with Russian protectionist policy leading the way. There is plenty of evidence of rising world protection before World War I (the unweighted average in the full sample rising from about $12 \%$ in 1865 to about $17 \%$ in 1910), and this drift towards more protection appeared everywhere except the Core (although the slow drift away from protection is driven entirely by the slow US retreat from its enormous Civil War tariffs), but it took place mainly in the Rich European Offshoots and the European Periphery. There is also evidence of a worldwide reversal of the pre-war drift towards protection after about 1900, but it did not include the LDCs which bucked the tide (led by Brazil, Colombia, Japan and the Philippines).

In the interwar decades, tariffs took two big leaps upward, and these took place world wide. The first leap was in the 1920s, which might be interpreted as a policy effort to return to 1914 levels. The second was in the 1930s, with aggressive beggar-my-neighbor policies reinforced by the specific-duty-

\footnotetext{
${ }^{6}$ The US has always presented a problem to historians and economists alike. The canonical frontier economy with scarce labor and abundant resources, by 1900 it was the world's industrial leader (Wright 1990) and a central market for the exports from the rest of the world, especially Latin America. So, while the US was certainly a Rich European Offshoot, we allocate it to the Core.
} 
deflation effect. While tariffs shot up everywhere, the rank order of the four clubs by level of protection changed considerably. In 1914, and from high protection to low, the rank order was Rich European Offshoots, LDCs, European Periphery, and Core. In 1939, it was a tie between Core, Rich European Offshoots, and LDCs - all now matching the very high levels of protection reached by the Rich European Offshoots in the 1890s, and the less protectionist European Periphery — which had about regained its prewar tariff levels. This rank order made another even more important change after World War II: the LDCs rose to the top of the heap and the Rich European Offshoots dropped below both the LDCs and the Core.

While in a sequel to this paper we intend to explore the determinants of protection across countries between 1865 and 1950, Figure 2 should make it clear that the century before 1950 offers plenty of policy variance to learn more about the trade-growth connection.

Figure 3 plots a principal-trading-partners'-tariff index for the same regional clubs. It is calculated like this: first, we identify for each country which countries are its major trading partners (up to five); second, we calculate exports going to each major trading partner as a share of total country exports going to all major trading partners; third, we use these shares as weights by which to construct the average tariff faced by each country. Finally, we construct an unweighted average for each region.

Figure 3 tells us that in the two decades before World War I, every region faced lower tariff rates in their main export markets than they themselves erected against competitors in their own markets. The explanation, of course, is that the main export markets were located in the Core, where tariffs were much lower. Thus, the Periphery faced lower tariffs than did the Core (for the European Periphery this was true throughout, but for the LDCs it was true only up to just before 1900, when the US replaced Britain as a major export market for them). During the interwar, every club faced very similar tariff rates in export

\footnotetext{
${ }^{7}$ Figure 3 has also been constructed as a weighted average where the averages weight these indices by share of each country's exports in total regional club exports. It does not change the story much. See footnote 4.
} 
markets, but those rates were rising very steeply as the Core made the biggest policy switch—compared with the other three clubs—-from free trade to protection.

A well-developed theoretical literature on strategic trade policy 1 predicts that nations have an incentive to inflate their own terms of trade (but thereby lower global welfare) with tariff policy-a classic prisoner's dilemma. Inasmuch as favorable terms of trade translate into better growth performance and tariffs are non-prohibitive, we might expect the association between own tariffs and growth to depend upon the external tariff environment faced by the country in question. Other impacts upon the terms of trade, such as growth in export markets or varying transportation costs, could also change the association between own tariffs and growth in such a framework. Having observed a dramatic shift in the world tariff environment, we proceed to ask whether or not we can use this fact to help better understand the changing tariff-growth association.

\section{The Pre-World War II Tariff Impact}

This paper will use two basic models to explore the issues raised about the Trade-Growth Paradox: what has been called the accumulation model and what has been called the convergence model. Table 2 uses the convergence model to explore regional heterogeneity in overall growth performance and in the contribution of tariff policy to it.

The estimated own tariff impact repeats the world-wide finding in Table 1 that high tariffs were associated with good growth before World War II. The coefficient on the own tariff in Table 2 (columns 1 and 3 ) is +0.21 for $1875-1908$ and +0.66 for $1924-1934$, both significant. However, when we add the interaction between region and tariff rate, regional asymmetry appears. Compared with the Core $(+0.59$

\footnotetext{
${ }^{8}$ Exemplified by Dixit (1987) and recently surveyed in Bagwell and Staiger (2000).

${ }^{9}$ Both of these models were also used by O'Rourke (2000).
} 
before World War I and +1.92 after), tariffs were associated with much faster growth in the Rich European Offshoots $(+1.53$ and +3.08$)$. And compared with the Core, tariffs had a much smaller impact on growth in the LDCs $(+0.59$ vs +0.18 before the War and +1.92 vs +0.69 after). Finally, tariffs had a negative impact on growth in the European Periphery ( -0.17 before the War and -0.52 after), the standard late $20^{\text {th }}$ century result, but the only region for which that finding holds before World War II.

Before we search for explanations of the regional asymmetry, note what columns 1 and 3 in the Table 2 tell us about world divergence and convergence. While there was convergence within the Core up to World War I (Britain's close competitors were catching up), there was divergence world-wide, and it was manifested mainly by the falling behind of the European Periphery (-0.69) and the LDCs (-1.10), confirming Lant Pritchett's (1997) emphasis that there was "big time" divergence in the half century before World War I. However, according to column 3 of Table 2 those divergence forces pretty much evaporated during the Interwar, mostly, one supposes, due to slowdown in the Core, rather than due to speed up in the Periphery.

Table 3 asks whether the Tariff-Growth Paradox and the regional asymmetry effects disappear when we control for trading partners' tariff policies, for trading partners' growth performance, and for the industrial sophistication of the country imposing the tariffs. We begin by pointing out that the TariffGrowth Paradox persists: the coefficient is positive in all 14 columns in Table 3 except the last, and is significant in all 14 except the last two. Furthermore, tariff policy made an important (statistical) contribution to growth. The third entry (just below the t-statistic) associated with each explanatory variable is the beta coefficient, and it suggests that protection typically accounted for a quarter to two-fifths of country GDP per capita growth. Table 3 also replicates regional asymmetry of the tariff impact. For various samples (dictated by data availability), columns $1,3,5,8,10$, and 12 report what we found in Table 2: namely, a positive impact for the Core, an even bigger positive impact for the Rich European Offshoots, a much smaller impact in the LDCs, and a negative impact in the European Periphery. 
Now, does the Paradox or the regional asymmetry evaporate when we control for policy and growth conditions in each country's export market? Columns 2 and 9 add the GDP growth performance of principal trading partners. ${ }^{10}$ Booming foreign markets did not have a significant effect before World War I, either in terms of the t-statistic or in terms of the beta coefficient (column 2). We found this result surprising given the stress which W. Arthur Lewis has placed on this "engine of growth" (Lewis 1978: pp. 67-75). His "engine of growth" only emerges in the interwar years (column 9), when it was significant and powerful. However, even then, it does not erase the Paradox or the regional asymmetry effect. Columns 6 and 13 add the influence of tariff levels facing exporters in their main markets abroad. By themselves, these didn't matter much before World War I (when they varied around a low average), but they mattered a great deal in the Interwar (when they varied around a very high average). Thus, and consistent with the famous accounts of Lewis, Prebisch, Singer and others, the "engine of growth" was slowing down for the Periphery, partly because growth in export markets was slowing down, and partly because tariff barriers rose. These effects were big.

We then let the own tariff and principal trading partners' tariff interact in columns 7 and 14 . In the relatively less-protected pre-1914 world, trading partner tariffs do not appear to have a statistically significant impact on growth (column 6) but minor tariff wars-i.e. protecting against others' protectionhurt growth (column 7). This was not so in the interwar years, when skyrocketing partner tariffs made protection the only way to survive (column 14). Note that controlling for the interwar interaction between own and partner tariffs, own tariffs suddenly lose their positive effect on growth; that is, own tariffs helped growth during the Interwar entirely through the channel of minimizing the crushing impact of others' protection. Note that the Paradox and the regional asymmetry still persists.

\footnotetext{
${ }^{10}$ Here and everywhere else, growth in the home country (our dependent variable) is measured as growth in per capita GDP. Growth in trading partner countries, however, is measured as growth in aggregate GDP. The former is the most appropriate measure of welfare at home; the latter is the most appropriate measure of changing demand abroad for the home country's exports.
} 
Finally, did the industrial sophistication of the protecting country matter? Yes, it did. As a proxy, we add in columns 4 and 11 the share of the country's exports which were primary products. Those countries who specialized in primary products (and imported manufactures) had significantly lower growth rates, both before World War I and after. Yet, the Paradox and regional asymmetry still persist.

Table 4 strengthens what we've found thus far by replacing the convergence model with the factor accumulation model (D refers to the percentage change during the five years following the year in question, KL refers to a proxy for the capital-labor ratio, and RL refers to the land-labor ratio). Table 4 also offers a more detailed assessment of the tariff impact by comparing it with other variables commonly championed in the growth literature. We begin by noting that the Paradox appears in this model too, so the finding is not model-specific. However, we also note that GDP growth in each country's main export markets has a more powerful and significant impact with this model than with the convergence model. We have no explanation for this result.

Now, what about comparative importance? In the pre-World War I years, protection takes third place behind physical capital deepening (DKL) and human capital deepening (school enrollment rates). Still, the effect is significant and big, and it would be bigger to the extent that the observed accumulation rates were endogenous (as they surely were) and positively related to protection (which we are less sure of). Infant mortality, terms of trade improvements and population growth have very small effects by comparison. In the Interwar, pretty much the same result emerges, except that DRL replaces school enrollment rates as the second biggest effect.

\section{How the Changing World Environment Changed the Tariff-Growth Impact}

After World War 1, the positive impact of tariffs on growth appears to wane. Columns 1 and 5 of Table 5 reveal that the own tariff effect was cut in half in the Interwar, although the effect was still 
statistically significant and positive. Thus, the Paradox was still present, but it was much less powerful. Could the tremendous rise in trading partner tariffs (especially in the Core) and the collapse in so many export markets (especially in the Core) be to blame? That is, could the fact that tariff policies were almost perfectly correlated explain the result—all rising dramatically in the 1920s and 1930s? We explore this proposition by first looking at all interwar years combined - the 1920s, the fall into the Depression after 1929, and the recovery from the trough to World War II. It may be a mistake to do so, if things were different during the beggar-my-neighbor years in the 1930s. Still, we start with the whole Interwar in Table 5, and the last three columns of the table appear to reject the hypothesis that the presence of partner tariffs and partner growth serve to diminish the magnitude and kill the statistical significance of the interwar tariff effect. If these outside factors were responsible for undermining the pre-1914 positive tariff-growth effect, one would have expected exactly the opposite; that is, by controlling for conditions in foreign markets we should have strengthened the own tariff effect. We did not, at least when we looked at the Interwar as a whole.

But a very different story emerges when the Interwar period is broken down into two parts. Table 6 divides the period into 1919-1930 — which contains the rush to close borders, to delink from world markets, and the big crash, 1 and 1931-1934—which contains years of universally high tariffs and growth recovery. The expected result now emerges from the 1919-1930 period: when controlling for partner tariffs by themselves (column 2) or also by partner growth (column 4), the positive own tariff effect on growth becomes statistically significant and also regains the same magnitude it had before 1914. After controlling for the influence of a rapidly changing world environment, the Tariff-Growth Paradox emerges alive and well in the interwar decades.

\footnotetext{
${ }^{11}$ Recall that the dependent variable is average growth during the five years after the year in question, thus the 1930 data point covers the nadir of recession in 1933.
} 
The source of that ambiguity in Table 5 is now clearer: the complicating years are those of initial recovery from the Great Depression when tariff walls were high everywhere. Own tariffs still helped growth after 1931 (column 5; albeit to a lesser degree than before), but external effects are no longer statistically significant and do not help explain why the positive tariff-growth effect has decreased. Figure 3 suggests why the 1930s were so different. Under the universally high tariff barriers of this autarkic period between 1931 and 1939, there may not be sufficient variance in partner tariffs to capture their effect. Furthermore, those barriers shut out the effects of partner growth everywhere.

Have we simply divided up the Interwar in a fortuitous way that conveniently gives us the expected result? Table 7 shows what happens to Table 5 when we control for the business cycle over the whole interwar period, that is, merging the 1920s and 1930s again. The regressor CYC is calculated precisely as it was in O'Rourke (2000): it is the difference between actual and trend growth, where the latter is predicted from a simple model in which observed growth is regressed on time and time squared. That is, CYC measures short run deviations from long run growth trends. After we control for the Great Depression, the positive impact of own tariffs on growth (absent from column 8 in Table 5, and from column 8 in Table 6 ), returns (column 8 in Table 7). Furthermore, principal trading partners' tariff is now negative and highly significant. These results support our contention that the Table 6 separation of the 1930s from the 1920s is essential to understanding the Paradox.

Table 7 also addresses the possibility of an endogeneity bias in Tables 1-6. O'Rourke discusses a potential mechanism of reverse causation between our tariff regressor and what we take to be the dependent variable, GDP growth. In his narrative, prices go up in booms, eroding the share of import duties in total import values during a period when such duties were collected as specific tariffs. Growth subsequently slows down in the slump following the boom and prices fall, so that low tariffs are associated, spuriously, with poor growth. Controlling for booms and busts in Table 7 does not, however, 
diminish the positive tariff effect on growth either before 1914 (Table 7, column 4) or after 1918 (Table 7, column 8), once we account for partner tariffs.

Table 8 uses CYC in a slightly different way to reveal that countries were, indeed, "beggaring their neighbors" during the massive interwar global shutdown. The sign on the interaction of own tariffs with CYC suggests that although tariffs didn't help more during recessions than in booms before 1914 (column 3), they certainly did when the Depression hit (column 6) and especially during recovery in the 1930s (column 7). The interaction term in columns 6 and 7 means that, controlling for the large run-up in trading partner tariffs, countries that had been hit hardest by the crash grew faster in the 1930s with high tariffs than with low tariffs. The "beggar thy neighbor" policy may have exported depression, but it helped get rid of it at home. The beta coefficients imply that a one standard deviation decrease in CYC combined with a one standard deviation increase in tariffs (a 9.1\% increase in the level of import duties over imports) was associated with 0.44 standard deviations better growth performance $(+1.25 \%$ in average annual growth) during the 1930s.

Although the nature of the association between high tariffs and fast growth appears to have changed during the Interwar, it lived on; the positive pre-1914 tariff-growth association remained robust.

\section{What Changed after 1950 ?}

We arrive, then, at the paradox. While the positive association between protection and growth before 1939 doggedly refuses attempts to make it go away, the negative association after 1950 also refuses to disappear. Tables 5 and 6 suggest a line of inquiry: if changing world conditions were able to alter the positive tariff-growth effect during the Interwar, perhaps an even bigger change in the period since 1950 could have transformed the once helpful tariff into a burden. If so, exactly which evolving aspects of the global trade environment were responsible for the regime shift? 
We begin, logically, with the exact specification and data employed by Sachs and Warner (1995, Table 11 loc. cit.). We start from here because (since Barro 1991) this particular macro-growth regression framework has become the most familiar one and because the Sachs-Warner work is so widely cited. It will soon become clear, however, that we will need to move beyond this Sachs-Warner platform to grapple with the Paradox. Table 9 recreates different versions of the Sachs and Warner analysis, ${ }_{12}$ substituting our own tariff rate (averaged across 1970-1989) for their OPEN dummy. The dependent variable is average annual growth during the period 1970-1989. We find no positive effect from tariffs; rather, we find a negative one, and it is powerful in terms of beta coefficients. This is to be expected, since average tariff rates were one of five factors that Sachs and Warner used to construct OPEN. ${ }^{13}$ Note, however, that the tariff effect is strongly negative only when we control for the world environment, a conclusion reached by comparing columns 4 and 6. Furthermore, the inclusion of initial GDP per capita and other covariates (especially education) appear to sap the explanatory power of tariffs in columns 1-4. Why? Figure 4 suggests an answer: the richest and most educated countries were also those with the lowest tariff barriers during this period, so multicollinearity could be inflating the standard errors. The only way around this problem is to expand the sample, which we will do presently.

This initial experiment with the familiar Sachs-Warner framework is suggestive. The interaction between own and trading partner tariffs in Table 9's column 7 is positive, and we think this is central. A glance back to Figure 1 reveals that at the beginning of the time period analyzed by Sachs and Warner, worldwide tariffs began to drop from a high post-war plateau, ${ }^{14}$ reaching levels in the late 1970 s as low as

\footnotetext{
${ }^{12} \mathrm{POL}$ is a composite variable indicating extreme political repression and unrest. PRI70 and SEC70 are the primary and secondary school enrollment rates in 1970. GVXDXE is government consumption as a fraction of GDP, net of military and education spending. REVCOUP and ASSASSP respectively measure revolutions/coups per year and assassinations per capita during the period. PPI70DEV measures the relative price of investment goods. INV7089 is GDI/GDP, and POP60LAND is the 1960 population density.

${ }^{13}$ The other four include non-tariff barriers such as quotas, restrictions to the convertibility of currency, socialist government, and a state monopoly on major exports.

${ }^{14}$ It stayed on a high plateau between 1950 and 1970 since the move to free trade within the OECD was offset by a move to protection in Latin America, Asia and Africa. Only later (in the period analyzed by Sachs and Warner) did
} 
those of the liberal 1860s. The positive interaction term suggests that tariffs help only when others have them too. Since tariffs have been lower than ever before since the 1970s, perhaps that explains why own tariffs don't help much anymore.

The beta coefficient in column 2 of Table 9 suggests that a one standard deviation increase in own tariffs ( $+8.7 \%$ in terms of import duties over imports) would decrease average annual growth 1970-89 by 0.15 standard deviations (a decrease of $0.3 \%$ in average annual growth performance over 19 years). But the beta coefficients of column 6 indicate that if the same increase in own tariffs were accompanied by a two standard deviation increase in average trading partner tariffs $(+4.4 \%$ in terms of import duties over imports) then the net effect on growth would be (just) positive. The multicollinearity problem, however, requires a bigger and better sample in order to analyze this explanation in more detail.

Thus, Table 10 adopts a new specification and a new dataset. The data, described in detail in the Appendix, are taken from the World Bank and United Nations. They are annual, cover the full halfcentury between 1950 and 1997, include up to 110 countries in a given year, and will give us a much better chance to isolate the tariff effect. Before we do so, however, it is important to explore the new data with the old Sachs-Warner specification and their shorter time period. We do so in columns 1-5. The tariff effect is of similar significance and magnitude to that seen in Table 9 - perhaps even a little bigger on both counts, and little changes when we take the log of the tariff rate to make these results commensurable with previous tables. Despite the fact that the model has fundamentally changed and that the sources for all data except tariffs are different, the significance and impact of the tariff regressor has not changed in any real sense.

Columns 6-8 use the same specification to explore medium run growth, covering three more postwar decades, and with country fixed effects. In columns 1-5 the dependent variable is average annual growth over the two decades 1970-1989, but in columns 6-8 it is instead average annual growth 1950-1997

the followers chase the leaders. 
during the half-decade following the year in question. The finer grain of these data lifts the negative association between tariffs and growth above the fog of multicollinearity. The magnitude of the impact, as measured by the beta coefficient, is identical to what we saw when using the Sachs and Warner data and specification, but using annual data over a much longer postwar period allows us to properly assess its significance. Compare columns 5 and 7: the log of the tariff rate is negative and insignificant 1970-1989, but negative and very significant 1950-1997. However, and once again, the changing world tariff environment appears capable of explaining the negative growth impact of tariffs. That is, adding the tariff index for trading partners and its interaction with the own tariff makes all the difference: the coefficient on the log of the own tariff rate switches sign (but loses significance). The beta coefficients of column 8 also suggest that the medium-term growth impact of tariffs is more susceptible to world environment than the long-term impact seen in Table 9.

A quantitative example is once again enlightening. The beta coefficients of column 7 in Table 10 show that a one standard deviation increase in logged own tariffs (equivalent to $+3.6 \%$ in terms of import duties over imports) in a given year was associated with a $1.1 \%$ drop in average annual growth during the subsequent five year period. ${ }^{15}$ But the beta coefficients of column 8 imply that just over a one standard deviation increase in average trading partner tariffs $(+4.0 \%$ in terms of import duties over imports) would be sufficient to (just) offset such a change. In rough terms: after 1950, raising tariffs by $4 \%$ would hurt growth, unless everyone were doing the same-in which case the $4 \%$ rise in own tariffs would actually help medium-term growth relative to the counterfactual.

We hypothesize, then, that currently low levels of trading partner tariffs explain why the association between own tariffs and growth switched from positive to negative over the past century.

\footnotetext{
${ }^{15}$ We emphasize that these numbers are not strictly comparable with the magnitude of the effect seen in the Sachs and Warner framework, since the former captures short-term fluctuations and the latter only long-term swings.
} 
Table 11 puts this hypothesis to the test, alongside competing explanations.16 Columns 1-3 test the whole 1950-1997 sample, column 4 tests only the Sachs-Warner period 1970-1989, and column 5 limits the 1950-1997 test to only those 35 countries we examined in the pre-World War I period.

The first competing explanation for the Tariff-Growth Paradox is that countries with access to high-growth markets for their exports in the postwar boom were able to grow faster, and entered into mutual tariff-reduction agreements in order to gain such access. Their growth, then, would be negatively correlated with tariffs due to a change in the growth performance of their trading partners. In this case, we could expect a positive coefficient on average trading partner growth and a negative interaction between tariffs and the partner growth effect. We do, in fact, observe these in Table 11.

The second alternative explanation is that a large decline in world transportation costs differentiates the present day from the pre-1914 era. Average effective distance from trading partners, measured as the product of physical distance and a transportation cost index and weighted by exports to

\footnotetext{
${ }^{16}$ In choosing among available datasets for the analysis of Tables 10 and 11, we had to make a tradeoff between coverage and quality. As of this writing, the Summers and Heston dataset is only available publicly in a form that extends through 1992, and since our dependent variable measures growth in the five years following the year in question, using these data would mean ignoring tariff behavior after 1987. For this reason we use IMF data on real GDP per capita growth, which cover through the present day (as well as more countries). Using IMF growth data has the additional advantage of limiting the number of different data sources we use, since we are already employing IMF trade flow data in the construction of the trading partner averages. Cognizant of the superior quality of the Summers and Heston growth numbers, however, we tested our results for sensitivity to using them instead. In fact, there are no substantive changes. If we use the Summers and Heston growth numbers for the period 1970-1987 on the left-hand side in Table 11 (thus working with, in rough terms, an annual version of the Sachs and Warner dataset), then: 1) the interaction term between own tariffs and partner tariffs is still positive and statistically significant, 2) the other interaction terms have the same sign shown in Table 11, and 3) the beta coefficients on the interaction terms are also similar-with the beta coefficient on the partner tariff interaction term being far larger than that on the partner growth and partner effective distance interaction terms. In brief, using the Summers and Heston growth numbers changes nothing about the conclusions reached in Table 11.

${ }^{17}$ Note that the sign on logged own tariffs is positive after including the interaction terms, in columns 2 through 5. This does not mean that the own tariff effect is positive; indeed we see in column 1 of Table 11 as well as all of Table 10 that it is negative, statistically significant, and economically powerful. Rather, in the presence of the interaction term this positive coefficient represents in some sense a "baseline" value of the tariff effect, which is modified in the ways indicated by the various interaction terms to arrive at the net effect seen in column 1 . For example, the positive coefficient on own tariffs in column 3 of Table 11 implies that, even after 1950, countries which faced sufficiently high trading partner tariffs, and/or sufficiently low trading partner growth, and/or sufficient high effective distance from trading partners, could in fact experience a positive effect of own tariffs on mediumterm growth. On the whole, however, growth was hurt by tariffs during this period, since the conditions described
} 
each trading partner, has declined for all countries since 1950. Perhaps the shrinking globe has meant that protectionists forego greater opportunities than they did in a less interconnected age. Were this true, we would expect a negative coefficient on effective distance and a positive interaction with tariffs; declining effective distance should make tariffs hurt growth more. Again, Table 11 confirms the effect.

A third competing hypothesis is that the rising postwar importance of non-tariff barriers (like quotas and currency restrictions) killed the positive association between tariffs and growth observed before World War II. This view would hold that tariffs are negatively correlated with growth today primarily because they serve as a proxy for omitted domestic economic liberalization indicators, and that tariffs per se have dwindling importance. Were this true, we would expect the inclusion of the Sachs-Warner OPEN variable to diminish the magnitude and significance of the tariff impact. We do not observe this; compare the beta coefficient on own tariffs from column 6 of Table $10(-0.199)$ with that of column 1 in Table 11 (0.227). Both are highly statistically significant, but the latter controls for OPEN and the former does not. Apparently, the inclusion of OPEN has not diminished the importance of tariffs. We might, however, expect tariffs to hurt growth more in more OPEN economies. A simultaneous increase in tariffs and OPEN would mean that quotas are being eliminated, currency exchange liberalized, and major exporters privatized, but at the same time large tariff walls are being erected. Such a process might generate inefficient rents for protected sectors able to take advantage of an otherwise open economy, skewing the distribution of income towards politically powerful industries and potentially harming overall growth. Of course, we rarely see tariffs and OPEN rising or falling together.

In short, we find evidence in support of the first and second, but not the third, competing hypothesis. That is, changes in partner growth and effective distance to partners after 1950 are able to explain part of the shift from a positive to a negative effect of own tariffs on growth, just as changing partner tariffs can explain part of the same shift. Which of these three forces, was the most important?

did not hold. 
Columns 3-5 of Table 11 make it clear that none of the competing explanations has the same explanatory power as that which asserts that the world tariff environment has been the key reason for the changing association between own tariffs and growth. A comparison of the beta coefficients on all the relevant interaction terms reveals that declining partner tariffs are capable of pushing the positive association between own tariffs and growth the furthest into the negative range. In column 3 , the beta coefficient on the interaction between partner tariffs and own tariffs is 0.57 ; for partner growth the corresponding number is -0.31 , and for effective distance it is 0.18 . An increase in own tariffs after 1950 hurt growth, but they would not have hurt growth in a hypothetical world in which trading partners' tariffs were higher, trading partners' growth were lower, and/or trading partners were more "effectively distant" (i.e., transportation costs were higher). Among these, the magnitude of the first effect is greatest. This conclusion does not change for column 4, where we restrict the time period to $1970-89$, nor for column 5, where we restrict the sample of countries to the same 35 analyzed before 1950.

\section{Other Explanations for the Tariff-Growth Paradox}

There is certainly no shortage of potential explanations for the post-1950 change in the tariffgrowth relationship that do not require an appeal to a changing world environment. These include:

Tariffs don't matter much today since non-tariff barriers are so much more important. The evidence in Table 11 rejects this view: the negative tariff effect survives the addition of OPEN, the SachsWarner multi-component variable that includes non-tariff barriers, socialist interventions, and currency convertibility restrictions. Own tariff and OPEN are, of course, correlated (partial correlation coefficient 0.369 across all countries and all years). But when both are included in the regression, one would expect OPEN to capture solely non-tariff effects. The beta coefficient on OPEN in column 1 of Table 11 is not 
larger in magnitude than that on own tariffs, suggesting that tariffs share comparable importance with nontariff barriers.

Tariffs matter early in the industrialization process, when they protect infant industries, but not later when economies are more mature. The evidence seems to be inconsistent with this view too. When the sample underlying column 1 Table 11 is restricted to only developing countries (arbitrarily, GDP per capita less than $\$ 3,500$ ) the magnitude of the negative tariff effect is still large and still statistically significant. Since the effect does not reverse when considering only those countries which today are at an early stage of industrialization, it seems unlikely that this explanation could account for the difference between pre-1914 and today. Of course, the explanation may certainly help explain why there was regional asymmetry before 1914 — very weak or no positive tariff-growth effects in the Periphery—to the extent that these countries were then clearly pre-industrial and incapable of modern economic growth.

Before 1914, governments that protected spent tariff revenues well on activities that promoted growth; in today's protected LDCs, governments squander tariff (and other) revenue on graft and other unproductive activities. Although we can only tangentially address this issue, we do see in Table 9 that the tariff effect survives inclusion of government consumption spending as a fraction of GDP net of military and education spending (GVXDXE).

There was a shift in the type of goods to which tariffs were applied, and tariffs on different goods have different effects on growth. Our data do not permit a test of this hypothesis since our tariff figures are aggregate. Yet Tables 5, 6, 9, and 10 all show how changing world environment can explain the changing influence of own tariffs, without recourse to tariff data disaggregated by product.

\section{Condusion}

We find that the best explanation for the Tariff-Growth Paradox is the fact that since the second 
World War, tariff barriers faced by the average exporting country have fallen to their lowest levels in a century and a half. A fter accounting for this change, there is no incompatibility between the less wellknown positive tariff-growth correlation before 1914 and the very well-known negative tariff-growth correlation since 1970. Other potential explanations cannot compete.

In a larger sense, we find that it has not always been true that protected countries finish last, and it need not be true in the future either. There is growing evidence suggesting that the benefits of openness, one of the cornerstones of the W ashington Consensus and the GATT/WTO negotiations, are neither inherent nor irreversible but rather depend upon the state of the world. In a very real sense, heads of state considering the move to openness are facing a game, rather than an isolated decision.

In such a world, the low-level equilibrium of mutually high tariffs is only as far away as some big world event that persuades influential leader-countries to switch to anti-global policies. Feedback ensures that the rest must follow in order to survive. As well, the high-level equilibrium of low tariffs we now enjoy was only as far away as the nascent OECD coordination of the early postwar years, and the creation of trans-national public institutions whose express purpose was to impede the return to interwar autarky.

But what sparks such shifts from one equilibrium to another? Who leads and who follows? Why did it happen in the 1920s and 1950s-and could it happen again? In forthcoming work, tariffs will migrate from the right hand side of our regressions to the left, and we will use an expanded version of our dataset to describe and explain the dynamics of these changes. 


\section{References}

Anderson, James E. 1998. “Trade Restrictiveness Benchmarks.” Economic Journal 108 (July): 1111-25.

Anderson, James E. and J. Peter Neary. 1994. "Measuring the Restrictiveness of Trade Policy.” World Bank Economic Review 8 (May): 151-69.

Bagwell, Kyle and Robert W. Staiger, 2000. "GATT-Think.” National Bureau of Economic Research Working Paper Series No. 8005. Cambridge, Mass.: NBER.

Bairoch, Paul. 1972. "Free Trade and European Economic Development in the $19^{\text {th }}$ Century." European Economic Review 3 (November): 211-45.

Baldwin, Robert E. 1969. “The Case Against Infant-Industry Tariff Protection.” Journal of Political Economy 77 (May/June): 295-305.

Barro, Robert J. 1991, “Economic Growth in a Cross Section of Countries.” Quarterly Journal of Economics 106 (May):407-443.

Bhagwati, Jagdish and Anne O. Krueger (eds.). 1973-1976. Foreign Trade Regimes and Economic

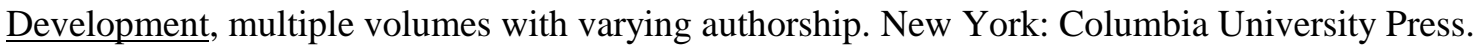

Bloom, David E. and Jeffrey G. Williamson. 1998. "Demographic Transitions and Economic Miracles in Emerging Asia.” World Bank Economic Review 12 (September): 419-55.

Capie, Forrest. 1983. "Tariff Protection and Economic Performance in the Nineteenth Century." In J. Black and L. A. Winters (eds.), Policy and Performance in International Trade. London: Macmillan.

Dixit, Avinash 1987. "Strategic Aspects of Trade Policy," in Truman F. Bewley, ed., Advances in Economic Theory: Fifth World Congress. New York: Cambridge University Press.

Dollar, David. 1992. “Outward-Oriented Developing Economies Really Do Grow More Rapidly: Evidence from 95 LDCs, 1976-1985.” Economic Development and Cultural Change 40 (April): 523-44. 
Dollar, David and Aart Kraay. 2000. "Trade, Growth, and Poverty." Manuscript, World Bank (October).

Eckes, Alfred, 1995. Opening America's Market: U.S. Foreign Trade since 1776. Chapel Hill: University of North Carolina Press.

Edwards, Sebastian. 1993. “Openness, Trade Liberalization, and Growth in Developing Countries.” Journal of Economic Literature 31 (September): 1358-94.

Frankel, Jeffrey and David Romer 1999. “Does Trade Cause Growth?” American Economic Review 89 (June): 379-399.

Irwin, Douglas A. 1996. "Changes in U.S. Tariffs: The Role of Import Prices and Commercial Policies?" American Economic Review 88 (September): 1015-26.

Irwin, Dougles A. 2001. "Tariffs and Growth in Late Nineteenth Century America,” World Economy 24 (January):15-30.

Irwin, Douglas A. and Marko Terviö 2001. "Does Trade Raise Income? Evidence from the Twentieth Century.” Forthcoming, Journal of International Economics.

Krueger, Anne O. 1983. “The Effects of Trade Strategies on Growth.” Finance and Development 20 (June): 6-8.

Krueger, Anne O. 1984. “Trade Policies in Developing Countries.” In Ronald Jones and Peter Kenan (eds.), Handbook of International Economics, volume 1. Amsterdam: North-Holland.

Lewis, W. Arthur. 1978. The Evolution of the International Economic Order. Princeton: Princeton University Press.

Lindert, Peter H. and Jeffrey G. Williamson. 2001. "Does Globalization Make the World More Unequal?" NBER Working Paper 8228, National Bureau of Economic Research, Cambridge, Mass. (April).

O’Rourke, Kevin H. 1997. “Measuring Protection: A Cautionary Tale.” Journal of Development Economics 53 (June99): 169-83.

O'Rourke, Kevin H. 2000. "Tariffs and Growth in the Late 19th Century." Economic Journal 110 (April): 
456-83.

Pritchett, Lant. 1997. "Divergence, Big Time.” Journal of Economic Perspectives 11 (Summer): 3-18.

Sachs, Jeffrey D. and Andrew Warner. 1995. "Economic Reform and the Process of Global Integration." Brookings Papers on Economic Activity 1: 1-118.

Vamvakidis, Athanasios. 1997. "How Robust Is the Growth-Openness Connection? Historical Evidence." Mimeo. Cambridge, Mass.: Harvard University.

Williamson, Jeffrey G. 1998. “Globalization, Labor Markets and Policy Backlash in the Past.” Journal of Economic Perspectives 12 (Fall): 51-72.

Wright, Gavin 1990. “The Origins of American Industrial Success, 1879-1940.” American Economic Review 80 (September): 651-68. 


\section{Table 1}

\section{The Association between Tariffs and Growth: Yesterday versus Today}

\begin{tabular}{lrrrr} 
Included countries & All & All & All & All \\
Years per period & 1 & 1 & 1 & 1 \\
Time Interval & $1865-1908$ & $1919-1934$ & $1950-1998$ & $1970-1990$ \\
\hline In GDP/capita & & & & \\
& -1.50 & -17.2 & -6.01 & -14.1 \\
In tariff rate & -7.21 & -19.8 & -24.5 & -30.5 \\
& 0.582 & 1.31 & -2.88 & -1.39 \\
& 4.38 & 6.72 & -7.18 & -4.44 \\
\hline & & & & \\
Country dummies? & & & Yes & Yes \\
Time dummies? & Yes & Yes & No & No \\
& & & & \\
N & 1540 & 519 & 3255 & 1968 \\
R-Squared & 0.242 & 0.565 & 0.412 & 0.518 \\
Adj. R-Squared & 0.224 & 0.532 & 0.385 & 0.482
\end{tabular}

t-statistics are in italics. 


\section{Table 2}

\section{Tariff Impact by Region}

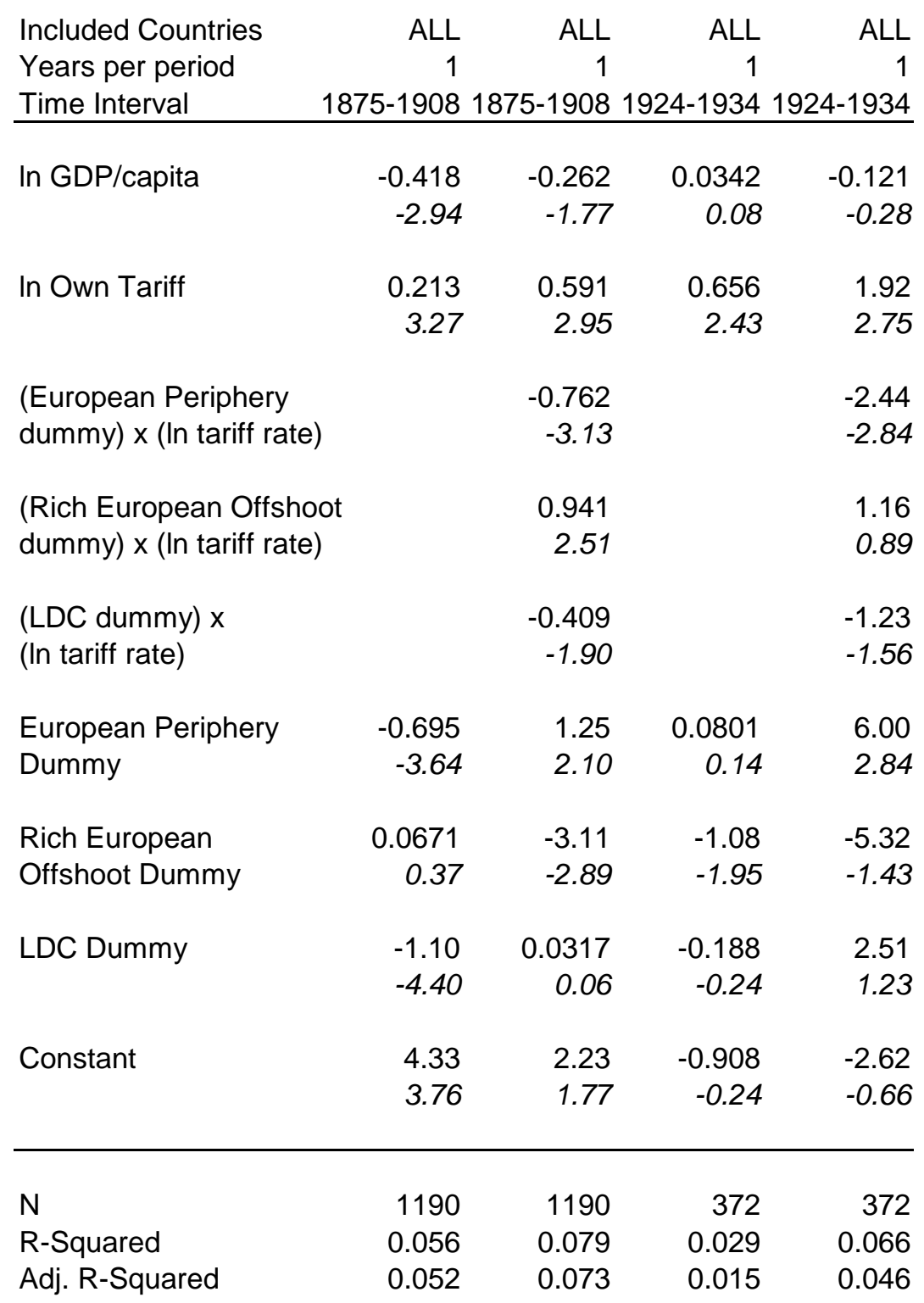

t-statistics are in italics. 


\section{Table 3: Can We Explain Regional Differences in Tariff Effects?}

\begin{tabular}{|c|c|c|c|c|c|c|c|}
\hline & (1) & (2) & (3) & (4) & (5) & (6) & (7) \\
\hline Included Countries & ALL & ALL & ALL & ALL & ALL & ALL & ALL \\
\hline Years per period & 1 & 1 & 1 & 1 & 1 & 1 & 1 \\
\hline Time Interval & $1875-1908$ & $1875-1908$ & $1875-1908$ & $1875-1908$ & $1875-1908$ & $1875-1908$ & $1875-1908$ \\
\hline \multirow[t]{2}{*}{ In GDP/capita } & $\begin{array}{r}-0.200 \\
-1.22\end{array}$ & $\begin{array}{r}-0.193 \\
-1.17\end{array}$ & $\begin{array}{r}-0.262 \\
-1.77\end{array}$ & $\begin{array}{r}-0.296 \\
-2.00\end{array}$ & $\begin{array}{r}-0.205 \\
-1.26\end{array}$ & $\begin{array}{r}-0.211 \\
-1.29\end{array}$ & $\begin{array}{r}-0.244 \\
-1.49\end{array}$ \\
\hline & -0.076 & -0.074 & -0.102 & -0.115 & -0.078 & -0.080 & -0.093 \\
\hline \multirow[t]{2}{*}{ In Own Tariff } & $\begin{array}{r}0.507 \\
2.42\end{array}$ & $\begin{array}{r}0.519 \\
2.47\end{array}$ & $\begin{array}{r}0.591 \\
2.95\end{array}$ & $\begin{array}{r}0.989 \\
3.95\end{array}$ & $\begin{array}{r}0.507 \\
2.43\end{array}$ & $\begin{array}{r}0.565 \\
2.64\end{array}$ & $\begin{array}{l}1.50 \\
3.14\end{array}$ \\
\hline & 0.227 & 0.232 & 0.283 & 0.474 & 0.228 & 0.254 & 0.674 \\
\hline \multirow{3}{*}{$\begin{array}{l}\text { (European Periphery } \\
\text { dummy) x (In tariff rate) }\end{array}$} & -0.756 & -0.747 & -0.762 & -1.03 & -0.760 & -0.825 & -0.912 \\
\hline & -2.81 & -2.78 & -3.13 & -3.92 & -2.84 & -3.03 & -3.32 \\
\hline & -0.604 & -0.597 & -0.576 & -0.781 & -0.608 & -0.660 & -0.729 \\
\hline \multirow{3}{*}{$\begin{array}{l}\text { (Rich European Offshoot } \\
\text { dummy) x (In tariff rate) }\end{array}$} & 0.776 & 0.776 & 0.941 & 0.551 & 0.829 & 0.671 & 0.815 \\
\hline & 1.72 & 1.72 & $\begin{array}{r}2.51 \\
0.728\end{array}$ & $\begin{array}{r}1.37 \\
0.426\end{array}$ & $\begin{array}{r}1.85 \\
0.689\end{array}$ & $\begin{array}{r}1.44 \\
0.558\end{array}$ & $\begin{array}{r}1.74 \\
0.678\end{array}$ \\
\hline & 0.646 & 0.646 & 0.728 & 0.426 & 0.689 & 0.558 & 0.678 \\
\hline \multirow{3}{*}{$\begin{array}{l}\text { (LDC dummy) } x \\
\text { (In tariff rate) }\end{array}$} & -0.240 & -0.263 & -0.409 & -0.769 & -0.328 & -0.443 & -0.501 \\
\hline & -1.00 & -1.09 & -1.90 & -3.02 & -1.38 & -1.75 & -1.97 \\
\hline & -0.158 & -0.173 & -0.314 & -0.590 & -0.223 & -0.301 & -0.340 \\
\hline \multirow{3}{*}{$\begin{array}{l}\text { European Periphery } \\
\text { Dummy }\end{array}$} & 1.33 & 1.29 & 1.25 & 2.24 & 1.33 & 1.53 & 1.81 \\
\hline & 1.99 & 1.94 & 2.10 & 3.19 & 2.00 & 2.24 & 2.61 \\
\hline & 0.390 & 0.380 & 0.354 & 0.632 & 0.390 & 0.446 & 0.530 \\
\hline \multirow{3}{*}{$\begin{array}{l}\text { Rich European } \\
\text { Offshoot Dummy }\end{array}$} & -2.47 & -2.49 & -3.11 & -1.66 & -2.65 & -2.25 & -2.58 \\
\hline & -1.84 & -1.85 & -2.89 & -1.38 & -1.99 & -1.64 & -1.88 \\
\hline & -0.654 & -0.659 & -0.776 & -0.414 & -0.701 & -0.595 & -0.684 \\
\hline \multirow[t]{2}{*}{ LDC Dummy } & $\begin{array}{r}-0.0251 \\
-0.04\end{array}$ & $\begin{array}{r}0.0208 \\
0.03\end{array}$ & $\begin{array}{r}0.0317 \\
0.06\end{array}$ & $\begin{array}{l}1.37 \\
1.84\end{array}$ & $\begin{array}{r}0.108 \\
0.18\end{array}$ & $\begin{array}{r}0.383 \\
0.59\end{array}$ & $\begin{array}{r}0.646 \\
0.98\end{array}$ \\
\hline & -0.007 & 0.006 & 0.010 & 0.419 & 0.031 & 0.109 & 0.184 \\
\hline $\begin{array}{l}\text { Growth of Principal } \\
\text { Trading Partners' GDP }\end{array}$ & & $\begin{array}{r}0.0243 \\
1.10 \\
0.036\end{array}$ & & & & & \\
\hline $\begin{array}{l}\text { Fraction of Exports Based } \\
\text { on Primary Products }\end{array}$ & & & & $\begin{array}{r}-1.14 \\
-2.64 \\
-0.149\end{array}$ & & & \\
\hline \multirow{3}{*}{$\begin{array}{l}\text { In Tariff Index for } \\
\text { Principal Trading Partners }\end{array}$} & & & & & & 0.182 & 1.32 \\
\hline & & & & & & 1.28 & 2.44 \\
\hline & & & & & & 0.050 & 0.364 \\
\hline $\begin{array}{l}\text { (In Own Tariff Index) x } \\
\text { (In Tariff Index for }\end{array}$ & & & & & & & $\begin{array}{r}-0.415 \\
-2.18\end{array}$ \\
\hline Principal Trading Partners) & & & & & & & -0.588 \\
\hline \multirow[t]{2}{*}{ Constant } & 1.96 & 1.82 & 2.23 & 2.11 & 2.00 & 1.50 & -0.858 \\
\hline & 1.40 & 1.29 & 1.77 & 1.68 & 1.44 & 1.04 & -0.48 \\
\hline $\mathrm{N}$ & 905 & 905 & 1190 & 1190 & 923 & 923 & 923 \\
\hline R-Squared & 0.068 & 0.069 & 0.079 & 0.084 & 0.067 & 0.069 & 0.074 \\
\hline Adj. R-Squared & 0.060 & 0.060 & 0.073 & 0.077 & 0.059 & 0.060 & 0.063 \\
\hline
\end{tabular}

t-statistics are in italics, beta coefficients in boldface. 


\section{Table 3 continued}

\begin{tabular}{|c|c|c|c|c|c|c|c|}
\hline & (8) & (9) & (10) & (11) & (12) & (13) & (14) \\
\hline Included Countries & ALL & ALL & ALL & ALL & ALL & ALL & ALL \\
\hline Years per perio & 1 & 1 & 1 & 1 & 1 & 1 & 1 \\
\hline Time Interval & 1924-1934 & 1924-1934 & 1924-1934 & $1924-1934$ & $1924-1934$ & $1924-1934$ & 1924-1934 \\
\hline \multirow{3}{*}{ In GDP/capita } & -0.0661 & 0.0753 & -0.121 & -0.257 & -0.188 & -1.17 & -1.00 \\
\hline & -0.16 & 0.19 & -0.28 & -0.59 & -0.43 & -260 & -2.23 \\
\hline & -0.016 & 0.019 & -0.030 & -0.063 & -0.045 & -0.280 & -0.241 \\
\hline \multirow[t]{3}{*}{ In Own Tariff } & 1.91 & 1.34 & 1.92 & 2.03 & 1.92 & 1.18 & -1.88 \\
\hline & 2.83 & 2.14 & 2.75 & 2.93 & 2.76 & 1.74 & -1.28 \\
\hline & 0.411 & 0.287 & 0.403 & 0.428 & 0.400 & 0.246 & -0.393 \\
\hline \multirow{3}{*}{$\begin{array}{l}\text { (European Periphery } \\
\text { dummy) } \times \text { (In tariff rate) }\end{array}$} & -2.03 & -1.54 & -2.44 & -2.41 & -2.47 & -2.84 & -2.51 \\
\hline & -2.40 & -1.98 & -2.84 & -2.83 & -2.88 & -3.46 & -3.02 \\
\hline & -0.845 & -0.642 & -1.02 & -1.001 & -1.03 & -1.19 & -1.05 \\
\hline \multirow{3}{*}{$\begin{array}{l}\text { (Rich European Offshoot } \\
\text { dummy) x (In tariff rate) }\end{array}$} & 1.19 & 0.734 & 1.16 & 1.27 & 1.12 & 0.389 & -0.241 \\
\hline & 0.94 & 0.63 & 0.89 & 0.98 & 0.86 & 0.31 & -0.19 \\
\hline & 0.530 & 0.326 & 0.495 & 0.544 & 0.482 & 0.167 & -0.104 \\
\hline \multirow{3}{*}{$\begin{array}{l}\text { (LDC dummy) } \mathrm{x} \\
\text { (In tariff rate) }\end{array}$} & -0.891 & -0.580 & -1.23 & -1.12 & -0.918 & -1.11 & -1.12 \\
\hline & -1.16 & -0.82 & -1.56 & -1.43 & -1.16 & -1.47 & -1.49 \\
\hline & -0.452 & -0.294 & -0.620 & -0.567 & -0.453 & -0.550 & -0.552 \\
\hline \multirow{3}{*}{$\begin{array}{l}\text { European Periphery } \\
\text { Dummy }\end{array}$} & 5.13 & 3.70 & 6.00 & 6.71 & 6.03 & 7.10 & 6.35 \\
\hline & 2.48 & 1.94 & 2.84 & 3.17 & 2.85 & 3.50 & 3.11 \\
\hline & 0.829 & 0.597 & 0.955 & 1.068 & 0.964 & 1.14 & 1.02 \\
\hline \multirow{3}{*}{$\begin{array}{l}\text { Rich European } \\
\text { Offshoot Dummy }\end{array}$} & -5.40 & -3.85 & -5.32 & -4.32 & -5.23 & -2.94 & -0.999 \\
\hline & -1.50 & -1.16 & -1.43 & -1.17 & -1.41 & -0.83 & -0.27 \\
\hline & -0.799 & -0.569 & -0.756 & -0.614 & -0.747 & -0.421 & -0.143 \\
\hline \multirow[t]{3}{*}{ LDC Dummy } & 1.80 & 1.39 & 2.51 & 3.34 & 1.69 & 1.37 & 1.58 \\
\hline & 0.90 & 0.76 & 1.23 & 1.63 & 0.82 & 0.70 & 0.81 \\
\hline & 0.323 & 0.249 & 0.442 & 0.589 & 0.294 & 0.238 & 0.276 \\
\hline \multirow[t]{2}{*}{$\begin{array}{l}\text { Growth of Principal } \\
\text { Trading Partners' GDP }\end{array}$} & & $\begin{array}{r}0.220 \\
8.10\end{array}$ & & & & & \\
\hline & & 0.397 & & & & & \\
\hline \multirow{2}{*}{$\begin{array}{l}\text { Fraction of Exports Based } \\
\text { on Primary Products }\end{array}$} & & & & $\begin{array}{l}-2.42 \\
-2.50\end{array}$ & & & \\
\hline & & & & -0.212 & & & \\
\hline \multirow{3}{*}{$\begin{array}{l}\text { In Tariff Index for } \\
\text { Principal Trading Partners }\end{array}$} & & & & & & 1.99 & -1.16 \\
\hline & & & & & & 5.83 & -0.84 \\
\hline & & & & & & 0.360 & -0.211 \\
\hline (In Own Tariff Index) $x$ & & & & & & & 1.24 \\
\hline (In Tariff Index for & & & & & & & 2.33 \\
\hline Principal Trading Partners) & & & & & & & 1.04 \\
\hline \multirow[t]{2}{*}{ Constant } & -3.073724 & -3.002109 & -2.615858 & -0.9203804 & -2.06212 & 2.865179 & 9.11453 \\
\hline & -0.79 & -0.84 & -0.66 & -0.23 & -0.52 & 0.73 & 1.93 \\
\hline $\mathrm{N}$ & 353 & 353 & 372 & 372 & 361 & 361 & 361 \\
\hline R-So & 0.084 & 0.231 & 0.066 & 0.082 & 0.079 & 0.160 & 0.173 \\
\hline Adj. $\mathrm{F}$ & 0.063 & 0.211 & 0.046 & 0.059 & 0.058 & 0.138 & 0.149 \\
\hline
\end{tabular}


Table 4: Comparing the Tariff Effect to Other Effects on Growth

\begin{tabular}{|c|c|c|c|c|c|c|c|c|c|c|}
\hline $\begin{array}{l}\text { Countries Included } \\
\text { Years Per Period } \\
\text { Time Interval } \\
\end{array}$ & $\begin{array}{r}\text { ALL } \\
1 \\
1875-1908 \\
\end{array}$ & $\begin{array}{r}\text { ALL } \\
1 \\
1875-1908 \\
\end{array}$ & $\begin{array}{r}\text { ALL } \\
1 \\
1875-1908 \\
\end{array}$ & $\begin{array}{r}\text { ALL } \\
1 \\
1875-1908 \\
\end{array}$ & $\begin{array}{r}\text { ALL } \\
1 \\
1875-1908 \\
\end{array}$ & $\begin{array}{r}\text { ALL } \\
1 \\
1919-1934 \\
\end{array}$ & $\begin{array}{r}\text { ALL } \\
1 \\
1919-1934 \\
\end{array}$ & $\begin{array}{r}\text { ALL } \\
1 \\
1919-1934 \\
\end{array}$ & $\begin{array}{r}\text { ALL } \\
1 \\
1919-1934 \\
\end{array}$ & $\begin{array}{r}\text { ALL } \\
1 \\
1919-1934 \\
\end{array}$ \\
\hline DKL & $\begin{array}{r}0.182 \\
8.77 \\
\mathbf{0 . 4 5 6}\end{array}$ & $\begin{array}{r}0.197 \\
8.61 \\
0.495\end{array}$ & $\begin{array}{r}0.230 \\
6.27 \\
\mathbf{0 . 4 1 8}\end{array}$ & $\begin{array}{r}0.151 \\
7.52 \\
0.405\end{array}$ & $\begin{array}{r}0.184 \\
8.79 \\
\mathbf{0 . 4 6 1}\end{array}$ & $\begin{array}{l}0.197 \\
10.97 \\
\mathbf{0 . 4 4 7}\end{array}$ & $\begin{array}{l}0.221 \\
11.39 \\
0.503\end{array}$ & $\begin{array}{l}0.257 \\
13.27 \\
\mathbf{0 . 5 1 0}\end{array}$ & $\begin{array}{r}0.158 \\
8.90 \\
0.365\end{array}$ & $\begin{array}{r}0.169 \\
6.15 \\
\mathbf{0 . 4 1 9}\end{array}$ \\
\hline DRL & $\begin{array}{r}0.0508 \\
1.99 \\
0.105\end{array}$ & $\begin{array}{r}0.00370 \\
0.12 \\
0.008\end{array}$ & $\begin{array}{r}-0.0958 \\
-1.92 \\
-0.147\end{array}$ & $\begin{array}{r}0.0555 \\
2.34 \\
\mathbf{0 . 1 2 5}\end{array}$ & $\begin{array}{r}0.0476 \\
1.84 \\
0.099\end{array}$ & $\begin{array}{r}0.204 \\
4.22 \\
\mathbf{0 . 1 7 6}\end{array}$ & $\begin{array}{r}0.120 \\
1.94 \\
\mathbf{0 . 1 0 4}\end{array}$ & $\begin{array}{r}0.224 \\
4.56 \\
\mathbf{0 . 1 8 0}\end{array}$ & $\begin{array}{r}0.216 \\
4.67 \\
\mathbf{0 . 1 9 1}\end{array}$ & $\begin{array}{r}0.241 \\
2.46 \\
\mathbf{0 . 1 5 2}\end{array}$ \\
\hline In Own Tariff & $\begin{array}{r}0.519 \\
3.12 \\
\mathbf{0 . 2 2 4}\end{array}$ & $\begin{array}{r}1.10 \\
4.52 \\
\mathbf{0 . 4 7 3}\end{array}$ & $\begin{array}{r}0.554 \\
2.27 \\
\mathbf{0 . 1 9 0}\end{array}$ & $\begin{array}{r}0.264 \\
1.59 \\
\mathbf{0 . 1 2 1}\end{array}$ & $\begin{array}{r}0.531 \\
3.18 \\
0.229\end{array}$ & $\begin{array}{r}0.593 \\
3.20 \\
\mathbf{0 . 1 3 8}\end{array}$ & $\begin{array}{r}0.825 \\
3.05 \\
\mathbf{0 . 1 9 2}\end{array}$ & $\begin{array}{r}0.545 \\
3.08 \\
0.126\end{array}$ & $\begin{array}{r}0.626 \\
3.54 \\
\mathbf{0 . 1 4 8}\end{array}$ & $\begin{array}{r}0.345 \\
1.14 \\
\mathbf{0 . 0 7 8}\end{array}$ \\
\hline $\begin{array}{l}\text { Fraction of population } \\
\text { under the age of } 15 \\
\text { enrolled in primary school }\end{array}$ & $\begin{array}{r}0.000252 \\
4.40 \\
\mathbf{0 . 2 5 3}\end{array}$ & $\begin{array}{r}0.000688 \\
4.33 \\
0.689\end{array}$ & $\begin{array}{r}0.000443 \\
4.28 \\
\mathbf{0 . 3 2 6}\end{array}$ & $\begin{array}{r}0.000265 \\
4.92 \\
\mathbf{0 . 2 8 5}\end{array}$ & $\begin{array}{r}0.000248 \\
4.30 \\
\mathbf{0 . 2 4 8}\end{array}$ & $\begin{array}{r}0.000112 \\
1.53 \\
\mathbf{0 . 0 7 3}\end{array}$ & $\begin{array}{r}-0.00000635 \\
-0.02 \\
-\mathbf{0 . 0 0 4}\end{array}$ & $\begin{array}{r}-0.0000448 \\
-0.53 \\
-0.029\end{array}$ & $\begin{array}{r}0.000116 \\
1.64 \\
0.076\end{array}$ & $\begin{array}{r}0.0000345 \\
0.33 \\
0.022\end{array}$ \\
\hline $\begin{array}{l}\text { Annual population } \\
\text { growth }\end{array}$ & $\begin{array}{r}0.108 \\
1.35 \\
0.074\end{array}$ & $\begin{array}{r}0.0783 \\
0.68 \\
0.054\end{array}$ & $\begin{array}{r}0.0764 \\
0.65 \\
\mathbf{0 . 0 4 6}\end{array}$ & $\begin{array}{r}0.262 \\
3.19 \\
\mathbf{0 . 1 8 1}\end{array}$ & $\begin{array}{r}0.120 \\
1.47 \\
\mathbf{0 . 0 8 2}\end{array}$ & $\begin{array}{r}-0.188 \\
-1.86 \\
-0.079\end{array}$ & $\begin{array}{r}-0.118 \\
-1.13 \\
-0.049\end{array}$ & $\begin{array}{r}-0.232 \\
-1.97 \\
-0.082\end{array}$ & $\begin{array}{r}-0.112 \\
-1.14 \\
-0.048\end{array}$ & $\begin{array}{r}-0.416 \\
-2.53 \\
-0.173\end{array}$ \\
\hline $\begin{array}{l}\text { Fraction of Exports } \\
\text { Based on Primary Products }\end{array}$ & $\begin{array}{r}-0.727 \\
-2.03 \\
-\mathbf{0 . 1 3 9}\end{array}$ & $\begin{array}{r}-3.81 \\
-3.82 \\
-0.729\end{array}$ & $\begin{array}{r}-0.433 \\
-0.93 \\
-0.101\end{array}$ & $\begin{array}{r}-0.387 \\
-1.14 \\
-0.079\end{array}$ & $\begin{array}{r}-0.754 \\
-2.10 \\
-\mathbf{0 . 1 4 4}\end{array}$ & $\begin{array}{r}-1.08 \\
-1.88 \\
-0.097\end{array}$ & $\begin{array}{r}-1.94 \\
-1.60 \\
-0.174\end{array}$ & $\begin{array}{r}-0.819 \\
-1.49 \\
-0.074\end{array}$ & $\begin{array}{r}-0.983 \\
-1.82 \\
-0.090\end{array}$ & $\begin{array}{r}-1.07 \\
-1.33 \\
-0.104\end{array}$ \\
\hline $\begin{array}{l}\text { Infant } \\
\text { Mortality }\end{array}$ & & & $\begin{array}{r}-0.000828 \\
-0.41 \\
-\mathbf{0 . 0 2 7}\end{array}$ & & & & & $\begin{array}{r}-0.00768 \\
-3.04 \\
-\mathbf{0 . 1 5 4}\end{array}$ & & \\
\hline $\begin{array}{l}\text { Growth of Principal } \\
\text { Trading Partners' GDP }\end{array}$ & & & & $\begin{array}{r}0.101 \\
2.36 \\
\mathbf{0 . 1 1 0}\end{array}$ & & & & & $\begin{array}{r}0.164 \\
7.40 \\
0.295\end{array}$ & \\
\hline $\begin{array}{l}\text { Change in } \\
\text { Terms of Trade }\end{array}$ & & & & & $\begin{array}{r}0.0151 \\
0.75 \\
0.035\end{array}$ & & & & & $\begin{array}{r}-0.0152 \\
-0.43 \\
-0.028\end{array}$ \\
\hline Constant & $\begin{array}{l}-1.10 \\
-3.29\end{array}$ & & $\begin{array}{l}-2.17 \\
-2.61\end{array}$ & $\begin{array}{l}-1.00 \\
-2.93\end{array}$ & $\begin{array}{l}-1.12 \\
-3.32\end{array}$ & $\begin{array}{r}0.111 \\
0.17\end{array}$ & & $\begin{array}{l}1.46 \\
1.92\end{array}$ & $\begin{array}{r}-0.290 \\
-0.47\end{array}$ & $\begin{array}{l}1.25 \\
1.30\end{array}$ \\
\hline Country Dummies? & No & Yes & No & No & No & No & Yes & No & No & No \\
\hline $\begin{array}{l}\mathrm{N} \\
\mathrm{R} \text { Squared } \\
\text { Adj R Squared }\end{array}$ & $\begin{array}{r}355 \\
0.289 \\
0.276\end{array}$ & $\begin{array}{r}355 \\
0.720 \\
0.705\end{array}$ & $\begin{array}{r}236 \\
0.270 \\
0.247\end{array}$ & $\begin{array}{r}341 \\
0.306 \\
0.291\end{array}$ & $\begin{array}{r}355 \\
0.290 \\
0.275\end{array}$ & $\begin{array}{r}498 \\
0.245 \\
0.235\end{array}$ & $\begin{array}{r}498 \\
0.499 \\
0.456\end{array}$ & $\begin{array}{r}480 \\
0.342 \\
0.332\end{array}$ & $\begin{array}{r}471 \\
0.328 \\
0.318\end{array}$ & $\begin{array}{r}227 \\
0.225 \\
0.200\end{array}$ \\
\hline
\end{tabular}


Figure 1: Unweighted World Average Own Tariff, 35 Countries, \%

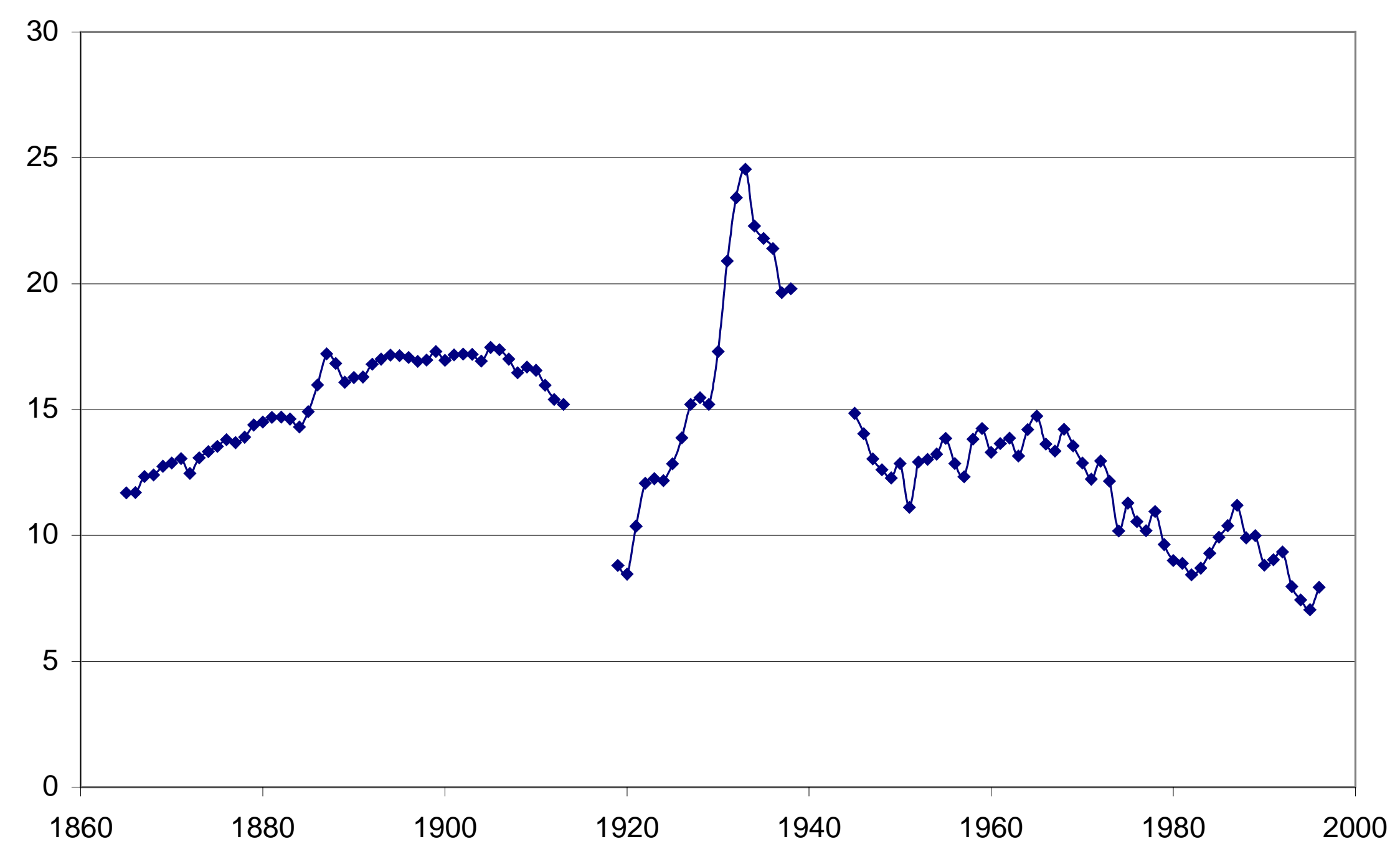


Figure 2: Unweighted Regional Average of OWN TARIFFS

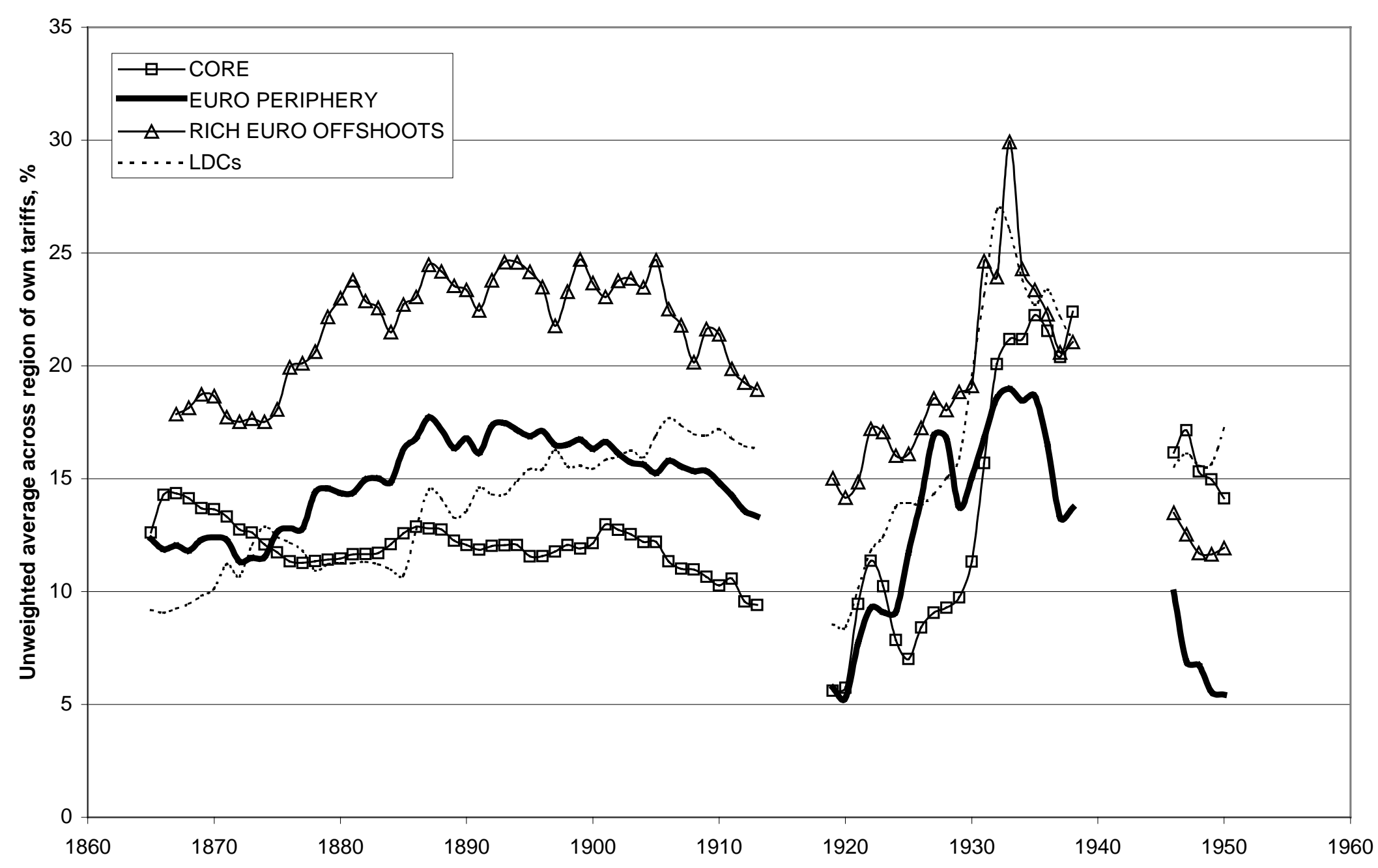


Figure 3: Unweighted Regional Averages of Index of Principal Trading Partners' Tariffs

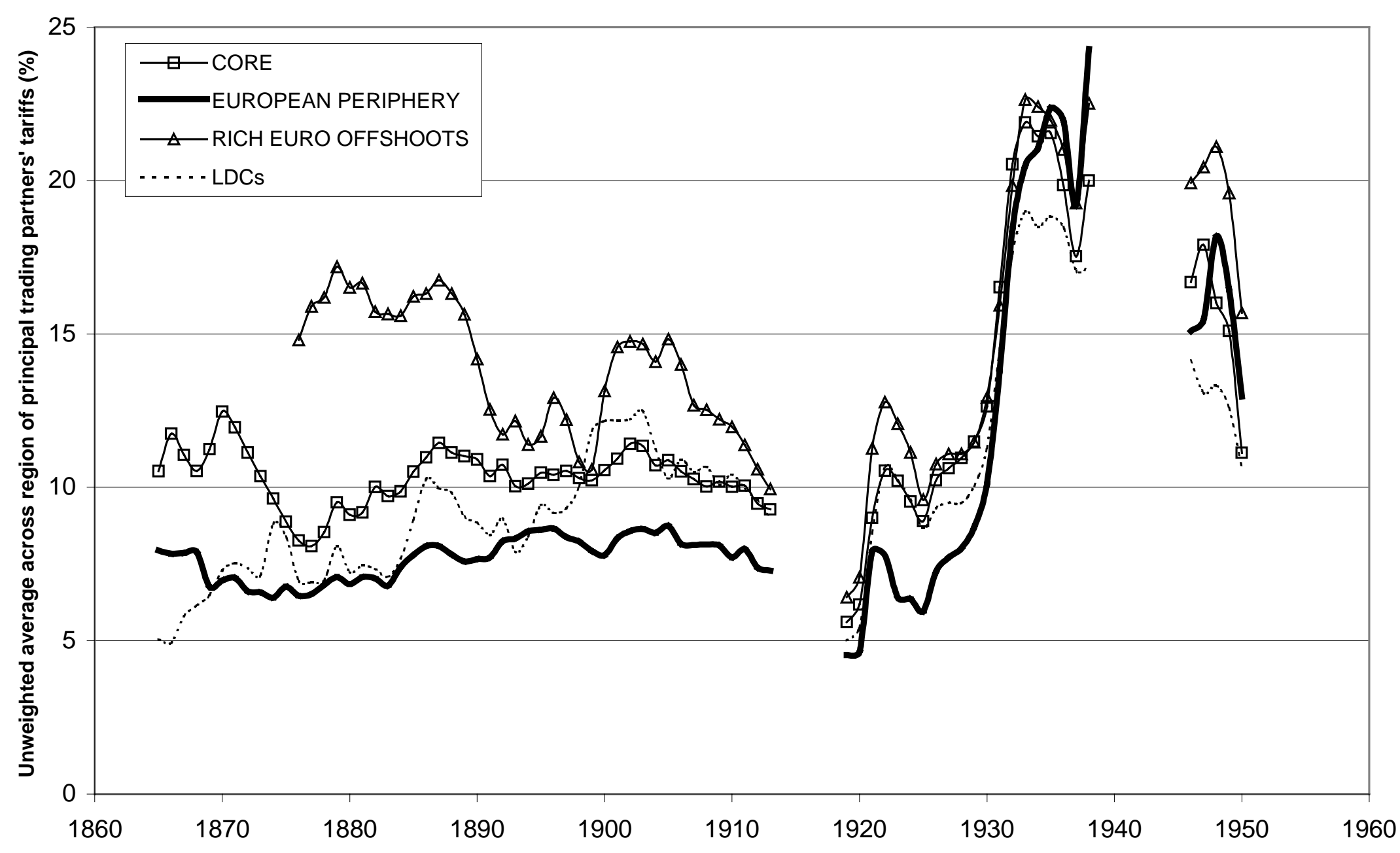


Table 5: Effects of the World Environment, Pre-World War 1 vs. Interwar

\begin{tabular}{|c|c|c|c|c|c|c|c|c|}
\hline $\begin{array}{l}\text { Countries Included } \\
\text { Years Per Period } \\
\text { Time Interval } \\
\end{array}$ & $\begin{array}{r}\text { ALL } \\
1 \\
1875-1908 \\
\end{array}$ & $\begin{array}{r}\text { ALL } \\
1 \\
1875-1908 \\
\end{array}$ & $\begin{array}{r}\text { ALL } \\
1 \\
1875-1908 \\
\end{array}$ & $\begin{array}{r}\text { ALL } \\
1 \\
1875-1908 \\
\end{array}$ & $\begin{array}{r}\text { ALL } \\
1 \\
1919-1934 \\
\end{array}$ & $\begin{array}{r}\text { ALL } \\
1 \\
1919-1934 \\
\end{array}$ & $\begin{array}{r}\text { ALL } \\
1 \\
1919-1934 \\
\end{array}$ & $\begin{array}{r}\text { ALL } \\
1 \\
1919-1934 \\
\end{array}$ \\
\hline DKL & $\begin{array}{r}0.176 \\
7.60 \\
\mathbf{0 . 4 4 2}\end{array}$ & $\begin{array}{r}0.166 \\
7.37 \\
\mathbf{0 . 4 4 7}\end{array}$ & $\begin{array}{r}0.163 \\
7.12 \\
\mathbf{0 . 4 3 9}\end{array}$ & $\begin{array}{r}0.163 \\
7.11 \\
\mathbf{0 . 4 3 9}\end{array}$ & $\begin{array}{l}0.207 \\
10.96 \\
\mathbf{0 . 4 6 9}\end{array}$ & $\begin{array}{l}0.203 \\
10.60 \\
\mathbf{0 . 4 6 4}\end{array}$ & $\begin{array}{r}0.142 \\
7.51 \\
0.330\end{array}$ & $\begin{array}{r}0.143 \\
7.51 \\
\mathbf{0 . 3 3 0}\end{array}$ \\
\hline DRL & $\begin{array}{r}-0.0396 \\
-1.26 \\
-0.082\end{array}$ & $\begin{array}{r}-0.0119 \\
-0.37 \\
-0.027\end{array}$ & $\begin{array}{r}-0.00978 \\
-0.30 \\
-0.022\end{array}$ & $\begin{array}{r}-0.00933 \\
-0.29 \\
-\mathbf{0 . 0 2 1}\end{array}$ & $\begin{array}{r}0.142 \\
2.30 \\
0.123\end{array}$ & $\begin{array}{r}0.140 \\
2.24 \\
0.122\end{array}$ & $\begin{array}{r}0.152 \\
2.67 \\
0.134\end{array}$ & $\begin{array}{r}0.151 \\
2.65 \\
\mathbf{0 . 1 3 3}\end{array}$ \\
\hline In Own Tariff & $\begin{array}{r}0.617 \\
6.05 \\
\mathbf{0 . 2 6 6}\end{array}$ & $\begin{array}{r}0.585 \\
2.19 \\
0.269\end{array}$ & $\begin{array}{r}0.529 \\
5.00 \\
0.243\end{array}$ & $\begin{array}{r}0.591 \\
2.21 \\
0.271\end{array}$ & $\begin{array}{r}0.381 \\
2.47 \\
\mathbf{0 . 0 8 9}\end{array}$ & $\begin{array}{r}0.206 \\
0.66 \\
\mathbf{0 . 0 4 8}\end{array}$ & $\begin{array}{r}0.299 \\
2.10 \\
0.071\end{array}$ & $\begin{array}{r}0.371 \\
1.27 \\
\mathbf{0 . 0 8 8}\end{array}$ \\
\hline $\begin{array}{l}\text { In Principal Trading } \\
\text { Partners' Tariff }\end{array}$ & & $\begin{array}{r}-0.0477 \\
-0.14 \\
-\mathbf{0 . 0 1 1}\end{array}$ & & $\begin{array}{r}-0.0873 \\
-0.25 \\
-\mathbf{0 . 0 2 0}\end{array}$ & & $\begin{array}{r}0.283 \\
0.85 \\
0.058\end{array}$ & & $\begin{array}{r}-0.0886 \\
-0.28 \\
-0.018\end{array}$ \\
\hline $\begin{array}{l}\text { Growth in Principal } \\
\text { Trading Partners' GDP }\end{array}$ & & & $\begin{array}{r}0.0324 \\
0.74 \\
\mathbf{0 . 0 3 5}\end{array}$ & $\begin{array}{r}0.0341 \\
0.77 \\
\mathbf{0 . 0 3 7}\end{array}$ & & & $\begin{array}{r}0.182 \\
8.01 \\
0.329\end{array}$ & $\begin{array}{r}0.184 \\
7.91 \\
\mathbf{0 . 3 3 1}\end{array}$ \\
\hline $\begin{array}{l}\text { Country Dummies? } \\
\text { Time Dummies? }\end{array}$ & $\begin{array}{r}\text { Yes } \\
\text { No }\end{array}$ & $\begin{array}{r}\text { Yes } \\
\text { No }\end{array}$ & $\begin{array}{r}\text { Yes } \\
\text { No }\end{array}$ & $\begin{array}{r}\text { Yes } \\
\text { No }\end{array}$ & $\begin{array}{r}\text { Yes } \\
\text { No }\end{array}$ & $\begin{array}{r}\text { Yes } \\
\text { No }\end{array}$ & $\begin{array}{r}\text { Yes } \\
\text { No }\end{array}$ & $\begin{array}{r}\text { Yes } \\
\text { No }\end{array}$ \\
\hline $\begin{array}{l}\mathrm{N} \\
\mathrm{R} \text { Squared } \\
\text { Adj R Squared }\end{array}$ & $\begin{array}{r}355 \\
0.697 \\
0.684\end{array}$ & $\begin{array}{r}341 \\
0.729 \\
0.715\end{array}$ & $\begin{array}{r}341 \\
0.729 \\
0.716\end{array}$ & $\begin{array}{r}341 \\
0.729 \\
0.715\end{array}$ & $\begin{array}{r}498 \\
0.489 \\
0.449\end{array}$ & $\begin{array}{r}479 \\
0.496 \\
0.455\end{array}$ & $\begin{array}{r}471 \\
0.575 \\
0.540\end{array}$ & $\begin{array}{r}471 \\
0.575 \\
0.539\end{array}$ \\
\hline
\end{tabular}


Table 6: A Closer Look at Effects of the World Environment during the Interwar Period

\begin{tabular}{|c|c|c|c|c|c|c|c|c|}
\hline $\begin{array}{l}\text { Countries Included } \\
\text { Years Per Period } \\
\text { Time Interval }\end{array}$ & $\begin{array}{r}\text { ALL } \\
1 \\
1919-1930 \\
\end{array}$ & $\begin{array}{r}\text { ALL } \\
1 \\
1919-1930 \\
\end{array}$ & $\begin{array}{r}\text { ALL } \\
1 \\
1919-1930 \\
\end{array}$ & $\begin{array}{r}\text { ALL } \\
1 \\
1919-1930 \\
\end{array}$ & $\begin{array}{r}\text { ALL } \\
1 \\
1931-1934 \\
\end{array}$ & $\begin{array}{r}\text { ALL } \\
1 \\
1931-1934 \\
\end{array}$ & $\begin{array}{r}\text { ALL } \\
1 \\
1931-1934 \\
\end{array}$ & $\begin{array}{r}\text { ALL } \\
1 \\
1931-1934 \\
\end{array}$ \\
\hline DKL & $\begin{array}{r}0.183 \\
9.17 \\
0.475\end{array}$ & $\begin{array}{r}0.189 \\
9.32 \\
0.490\end{array}$ & $\begin{array}{r}0.133 \\
6.53 \\
\mathbf{0 . 3 4 3}\end{array}$ & $\begin{array}{r}0.139 \\
6.87 \\
\mathbf{0 . 3 6 0}\end{array}$ & $\begin{array}{r}0.0650 \\
1.27 \\
\mathbf{0 . 1 0 7}\end{array}$ & $\begin{array}{r}0.0502 \\
0.94 \\
0.086\end{array}$ & $\begin{array}{r}0.0531 \\
0.83 \\
0.093\end{array}$ & $\begin{array}{r}0.0409 \\
0.64 \\
0.072\end{array}$ \\
\hline DRL & $\begin{array}{r}0.165 \\
2.27 \\
\mathbf{0 . 1 5 6}\end{array}$ & $\begin{array}{r}0.149 \\
2.04 \\
\mathbf{0 . 1 4 2}\end{array}$ & $\begin{array}{r}0.167 \\
2.43 \\
\mathbf{0 . 1 5 9}\end{array}$ & $\begin{array}{r}0.160 \\
2.35 \\
\mathbf{0 . 1 5 2}\end{array}$ & $\begin{array}{r}0.00163 \\
0.01 \\
0.001\end{array}$ & $\begin{array}{r}0.0101 \\
0.08 \\
0.008\end{array}$ & $\begin{array}{r}0.0771 \\
0.58 \\
0.067\end{array}$ & $\begin{array}{r}0.124 \\
0.91 \\
\mathbf{0 . 1 0 8}\end{array}$ \\
\hline In Own Tariff & $\begin{array}{r}-0.0847 \\
-0.45 \\
-0.020\end{array}$ & $\begin{array}{r}0.890 \\
2.43 \\
\mathbf{0 . 2 0 8}\end{array}$ & $\begin{array}{r}0.144 \\
0.79 \\
\mathbf{0 . 0 3 4}\end{array}$ & $\begin{array}{r}0.946 \\
2.77 \\
\mathbf{0 . 2 2 2}\end{array}$ & $\begin{array}{r}0.578 \\
2.21 \\
0.097\end{array}$ & $\begin{array}{r}-0.179 \\
-0.24 \\
-0.031\end{array}$ & $\begin{array}{r}0.639 \\
2.32 \\
\mathbf{0 . 1 3 0}\end{array}$ & $\begin{array}{r}-0.347 \\
-0.48 \\
-0.071\end{array}$ \\
\hline $\begin{array}{l}\text { In Principal Trading } \\
\text { Partners' Tariff }\end{array}$ & & $\begin{array}{r}-1.27 \\
-3.08 \\
-0.234\end{array}$ & & $\begin{array}{r}-1.07 \\
-2.77 \\
-0.196\end{array}$ & & $\begin{array}{r}0.875 \\
1.09 \\
0.095\end{array}$ & & $\begin{array}{r}1.25 \\
1.47 \\
0.158\end{array}$ \\
\hline $\begin{array}{l}\text { Growth in Principal } \\
\text { Trading Partners' GDP }\end{array}$ & & & $\begin{array}{r}0.200 \\
7.17 \\
0.336\end{array}$ & $\begin{array}{r}0.194 \\
7.02 \\
\mathbf{0 . 3 2 6}\end{array}$ & & & $\begin{array}{r}-0.00127 \\
-0.02 \\
-0.002\end{array}$ & $\begin{array}{r}-0.0421 \\
-0.66 \\
-\mathbf{0 . 0 7 8}\end{array}$ \\
\hline $\begin{array}{l}\text { Country Dummies? } \\
\text { Time Dummies? }\end{array}$ & $\begin{array}{r}\text { Yes } \\
\text { No }\end{array}$ & $\begin{array}{r}\text { Yes } \\
\text { No }\end{array}$ & $\begin{array}{r}\text { Yes } \\
\text { No }\end{array}$ & $\begin{array}{r}\text { Yes } \\
\text { No }\end{array}$ & $\begin{array}{r}\text { Yes } \\
\text { No }\end{array}$ & $\begin{array}{r}\text { Yes } \\
\text { No }\end{array}$ & $\begin{array}{r}\text { Yes } \\
\text { No }\end{array}$ & $\begin{array}{r}\text { Yes } \\
\text { No }\end{array}$ \\
\hline $\begin{array}{l}\mathrm{N} \\
\mathrm{R} \text { Squared } \\
\text { Adj R Squared }\end{array}$ & $\begin{array}{r}369 \\
0.484 \\
0.430\end{array}$ & $\begin{array}{r}354 \\
0.493 \\
0.437\end{array}$ & $\begin{array}{r}354 \\
0.550 \\
0.501\end{array}$ & $\begin{array}{r}354 \\
0.561 \\
0.511\end{array}$ & $\begin{array}{r}129 \\
0.881 \\
0.836\end{array}$ & $\begin{array}{r}125 \\
0.881 \\
0.835\end{array}$ & $\begin{array}{r}117 \\
0.896 \\
0.853\end{array}$ & $\begin{array}{r}117 \\
0.899 \\
0.855\end{array}$ \\
\hline
\end{tabular}

t-statistics are in italics, beta coefficients in boldface. 


\section{Table 7: Business Cycle Effects}

\begin{tabular}{|c|c|c|c|c|c|c|c|c|}
\hline $\begin{array}{l}\text { Countries Included } \\
\text { Years Per Period } \\
\text { Time Interval } \\
\end{array}$ & $\begin{array}{r}\text { ALL } \\
1 \\
1875-1908 \\
\end{array}$ & $\begin{array}{r}\text { ALL } \\
1 \\
1875-1908 \\
\end{array}$ & $\begin{array}{r}\text { ALL } \\
1 \\
1875-1908 \\
\end{array}$ & $\begin{array}{r}\text { ALL } \\
1 \\
1875-1908 \\
\end{array}$ & $\begin{array}{r}\text { ALL } \\
1 \\
1919-1934 \\
\end{array}$ & $\begin{array}{r}\text { ALL } \\
1 \\
1919-1934 \\
\end{array}$ & $\begin{array}{r}\text { ALL } \\
1 \\
1919-1934 \\
\end{array}$ & $\begin{array}{r}\text { ALL } \\
1 \\
1919-1934 \\
\end{array}$ \\
\hline DKL & $\begin{array}{r}0.176 \\
7.60 \\
\mathbf{0 . 4 4 2}\end{array}$ & $\begin{array}{r}0.167 \\
7.37 \\
\mathbf{0 . 4 4 7}\end{array}$ & $\begin{array}{r}0.00194 \\
0.17 \\
\mathbf{0 . 0 0 5}\end{array}$ & $\begin{array}{r}0.00653 \\
0.59 \\
\mathbf{0 . 0 1 8}\end{array}$ & $\begin{array}{l}0.207 \\
10.96 \\
\mathbf{0 . 4 6 9}\end{array}$ & $\begin{array}{l}0.203 \\
10.60 \\
\mathbf{0 . 4 6 4}\end{array}$ & $\begin{array}{r}0.0682 \\
5.80 \\
\mathbf{0 . 1 5 5}\end{array}$ & $\begin{array}{r}0.0683 \\
5.85 \\
\mathbf{0 . 1 5 6}\end{array}$ \\
\hline DRL & $\begin{array}{r}-0.0396 \\
-1.26 \\
-0.082\end{array}$ & $\begin{array}{r}-0.0119 \\
-0.37 \\
-\mathbf{0 . 0 2 7}\end{array}$ & $\begin{array}{r}0.0638 \\
4.51 \\
\mathbf{0 . 1 3 2}\end{array}$ & $\begin{array}{r}0.0788 \\
5.37 \\
\mathbf{0 . 1 7 7}\end{array}$ & $\begin{array}{r}0.142 \\
2.30 \\
0.123\end{array}$ & $\begin{array}{r}0.140 \\
2.24 \\
0.122\end{array}$ & $\begin{array}{r}0.114 \\
3.21 \\
0.099\end{array}$ & $\begin{array}{r}0.104 \\
2.95 \\
0.091\end{array}$ \\
\hline In Own Tariff & $\begin{array}{r}0.617 \\
6.05 \\
0.266\end{array}$ & $\begin{array}{r}0.585 \\
2.19 \\
\mathbf{0 . 2 6 9}\end{array}$ & $\begin{array}{l}0.615 \\
13.68 \\
0.265\end{array}$ & $\begin{array}{r}0.611 \\
5.08 \\
0.281\end{array}$ & $\begin{array}{r}0.381 \\
2.47 \\
0.089\end{array}$ & $\begin{array}{r}0.206 \\
0.66 \\
\mathbf{0 . 0 4 8}\end{array}$ & $\begin{array}{r}-0.0497 \\
-0.55 \\
-\mathbf{0 . 0 1 2}\end{array}$ & $\begin{array}{r}0.374 \\
2.10 \\
0.086\end{array}$ \\
\hline $\begin{array}{l}\text { In Principal Trading } \\
\text { Partners' Tariff }\end{array}$ & & $\begin{array}{r}-0.0477 \\
-0.14 \\
-\mathbf{0 . 0 1 1}\end{array}$ & & $\begin{array}{r}-0.0701 \\
-0.46 \\
-\mathbf{0 . 0 1 6}\end{array}$ & & $\begin{array}{r}0.283 \\
0.85 \\
\mathbf{0 . 0 5 8}\end{array}$ & & $\begin{array}{r}-0.467 \\
-2.47 \\
-0.095\end{array}$ \\
\hline CYC & & & $\begin{array}{r}0.875 \\
37.6 \\
\mathbf{0 . 8 0 9}\end{array}$ & $\begin{array}{r}0.854 \\
35.7 \\
\mathbf{0 . 8 1 2}\end{array}$ & & & $\begin{array}{r}0.936 \\
30.6 \\
\mathbf{0 . 7 1 1}\end{array}$ & $\begin{array}{r}0.943 \\
30.8 \\
0.721\end{array}$ \\
\hline $\begin{array}{l}\text { Country Dummies? } \\
\text { Time Dummies? }\end{array}$ & $\begin{array}{r}\text { Yes } \\
\text { No }\end{array}$ & $\begin{array}{r}\text { Yes } \\
\text { No }\end{array}$ & $\begin{array}{r}\text { Yes } \\
\text { No }\end{array}$ & $\begin{array}{r}\text { Yes } \\
\text { No }\end{array}$ & $\begin{array}{r}\text { Yes } \\
\text { No }\end{array}$ & $\begin{array}{r}\text { Yes } \\
\text { No }\end{array}$ & $\begin{array}{r}\text { Yes } \\
\text { No }\end{array}$ & $\begin{array}{r}\text { Yes } \\
\text { No }\end{array}$ \\
\hline $\begin{array}{l}\mathrm{N} \\
\mathrm{R} \text { Squared } \\
\text { Adj R Squared }\end{array}$ & $\begin{array}{r}355 \\
0.697 \\
0.684\end{array}$ & $\begin{array}{r}341 \\
0.729 \\
0.715\end{array}$ & $\begin{array}{l}355 \\
0.941 \\
0.939\end{array}$ & $\begin{array}{r}341 \\
0.945 \\
0.942\end{array}$ & $\begin{array}{r}498 \\
0.489 \\
0.449\end{array}$ & $\begin{array}{r}479 \\
0.496 \\
0.455\end{array}$ & $\begin{array}{r}498 \\
0.831 \\
0.818\end{array}$ & $\begin{array}{r}479 \\
0.840 \\
0.826\end{array}$ \\
\hline
\end{tabular}

t-statistics are in italics, beta coefficients in boldface. 


\section{Table 8: Beggar thy Neighbor}

CYC is calculated as the difference between actual growth and predicted growth, where predicted growth comes from regressing growth on time and time squared for each country

\begin{tabular}{|c|c|c|c|c|c|c|c|}
\hline $\begin{array}{l}\text { Included Countries } \\
\text { Years per period } \\
\text { Time Period } \\
\end{array}$ & $\begin{array}{r}\text { ALL } \\
1 \\
1875-1908 \\
\end{array}$ & $\begin{array}{r}\text { ALL } \\
1 \\
1875-1908 \\
\end{array}$ & $\begin{array}{r}\text { ALL } \\
1 \\
1875-1908 \\
\end{array}$ & $\begin{array}{r}\text { ALL } \\
1 \\
1919-34 \\
\end{array}$ & $\begin{array}{r}\text { ALL } \\
1 \\
1919-34 \\
\end{array}$ & $\begin{array}{r}\text { ALL } \\
1 \\
1919-34 \\
\end{array}$ & $\begin{array}{r}\text { ALL } \\
1 \\
1930-34 \\
\end{array}$ \\
\hline DKL & $\begin{array}{r}0.182 \\
7.78 \\
\mathbf{0 . 4 5 5}\end{array}$ & $\begin{array}{r}0.00765 \\
0.68 \\
0.0206\end{array}$ & $\begin{array}{r}0.00530 \\
0.47 \\
\mathbf{0 . 0 1 4 2}\end{array}$ & $\begin{array}{l}0.218 \\
11.30 \\
\mathbf{0 . 4 9 6}\end{array}$ & $\begin{array}{r}0.0678 \\
5.23 \\
\mathbf{0 . 1 5 5}\end{array}$ & $\begin{array}{r}0.0530 \\
4.33 \\
\mathbf{0 . 1 2 1}\end{array}$ & $\begin{array}{r}0.0601 \\
2.58 \\
0.103\end{array}$ \\
\hline DRL & $\begin{array}{r}-.0255 \\
-0.79 \\
-0.053\end{array}$ & $\begin{array}{r}0.0738 \\
4.95 \\
\mathbf{0 . 1 6 6}\end{array}$ & $\begin{array}{r}0.0801 \\
5.35 \\
\mathbf{0 . 1 8 0}\end{array}$ & $\begin{array}{r}0.129 \\
2.09 \\
\mathbf{0 . 1 1 1}\end{array}$ & $\begin{array}{r}0.107 \\
3.11 \\
0.0934\end{array}$ & $\begin{array}{r}0.117 \\
3.36 \\
\mathbf{0 . 1 0 2}\end{array}$ & $\begin{array}{r}0.0553 \\
0.97 \\
0.0447\end{array}$ \\
\hline In tariff rate & $\begin{array}{r}1.06 \\
3.84 \\
\mathbf{0 . 4 5 6}\end{array}$ & $\begin{array}{l}2.36 \\
3.34 \\
1.09\end{array}$ & $\begin{array}{r}0.620 \\
4.58 \\
0.285\end{array}$ & $\begin{array}{r}0.841 \\
3.50 \\
0.196\end{array}$ & $\begin{array}{r}1.60 \\
3.14 \\
0.369\end{array}$ & $\begin{array}{r}0.0459 \\
0.24 \\
0.0106\end{array}$ & $\begin{array}{r}0.0694 \\
0.19 \\
0.0121\end{array}$ \\
\hline In partners' tariffs & & $\begin{array}{r}1.83 \\
2.33 \\
0.410\end{array}$ & $\begin{array}{r}-0.0681 \\
-0.29 \\
-\mathbf{0 . 0 1 5 3}\end{array}$ & & $\begin{array}{r}1.08 \\
1.97 \\
0.220\end{array}$ & $\begin{array}{r}-0.619 \\
-3.24 \\
-0.126\end{array}$ & $\begin{array}{r}-0.153 \\
-0.40 \\
-0.0195\end{array}$ \\
\hline $\begin{array}{l}\text { (In tariff rate) } x \\
\text { (In partners' tariffs) }\end{array}$ & & $\begin{array}{r}-0.778 \\
-2.52 \\
-0.863\end{array}$ & & & $\begin{array}{r}-0.688 \\
-3.32 \\
-0.617\end{array}$ & & \\
\hline CYC & & $\begin{array}{r}0.850 \\
35.7 \\
0.808\end{array}$ & $\begin{array}{r}0.779 \\
8.39 \\
\mathbf{0 . 7 4 1}\end{array}$ & & $\begin{array}{r}0.988 \\
31.6 \\
0.756\end{array}$ & $\begin{array}{r}1.14 \\
7.14 \\
0.875\end{array}$ & $\begin{array}{l}1.52 \\
5.95 \\
1.15\end{array}$ \\
\hline $\begin{array}{l}(\mathrm{CYC}) \mathrm{x} \\
\text { (In tariff rate) }\end{array}$ & & & $\begin{array}{r}0.0292 \\
0.83 \\
\mathbf{0 . 0 7 4 1}\end{array}$ & & & $\begin{array}{r}-0.0603 \\
-1.03 \\
-0.128\end{array}$ & $\begin{array}{r}-0.195 \\
-2.29 \\
-0.443\end{array}$ \\
\hline $\begin{array}{l}\text { Country dummies? } \\
\text { Period dummies? }\end{array}$ & $\begin{array}{l}\text { Yes } \\
\text { No }\end{array}$ & $\begin{array}{l}\text { Yes } \\
\text { No }\end{array}$ & $\begin{array}{r}\text { Yes } \\
\text { No }\end{array}$ & $\begin{array}{l}\text { Yes } \\
\text { No }\end{array}$ & $\begin{array}{l}\text { Yes } \\
\text { No }\end{array}$ & $\begin{array}{l}\text { Yes } \\
\text { No }\end{array}$ & $\begin{array}{r}\text { Yes } \\
\text { No }\end{array}$ \\
\hline $\begin{array}{l}\mathrm{N} \\
\text { R-Squared } \\
\text { Adj. R-Squared }\end{array}$ & $\begin{array}{r}355 \\
0.352 \\
0.323\end{array}$ & $\begin{array}{r}341 \\
0.868 \\
0.860\end{array}$ & $\begin{array}{r}341 \\
0.865 \\
0.858\end{array}$ & $\begin{array}{r}498 \\
0.390 \\
0.343\end{array}$ & $\begin{array}{r}479 \\
0.818 \\
0.802\end{array}$ & $\begin{array}{r}479 \\
0.813 \\
0.797\end{array}$ & $\begin{array}{r}156 \\
0.943 \\
0.926\end{array}$ \\
\hline
\end{tabular}

t-statistics are in italics, beta coefficients in boldface. 


\section{Table 9: Starting from a Familiar Framework}

\begin{tabular}{|c|c|c|c|c|c|c|c|}
\hline Dependent Variable & G7089 & G7089 & G7089 & G7089 & G7089 & G7089 & G7089 \\
\hline LGDP70 & & $\begin{array}{r}0.00169 \\
0.79 \\
\mathbf{0 . 0 8 5}\end{array}$ & $\begin{array}{r}-1.12 \\
-4.53 \\
-0.555\end{array}$ & $\begin{array}{r}-1.35 \\
-4.28 \\
-0.641\end{array}$ & $\begin{array}{r}0.00430 \\
2.00 \\
\mathbf{0 . 2 2 1}\end{array}$ & $\begin{array}{r}0.00342 \\
1.53 \\
0.176\end{array}$ & $\begin{array}{r}-0.0115 \\
-3.50 \\
-0.556\end{array}$ \\
\hline Tariff Rate & $\begin{array}{r}-0.0437 \\
-2.14 \\
-0.197\end{array}$ & $\begin{array}{r}-0.0333 \\
-1.35 \\
-\mathbf{0 . 1 4 7}\end{array}$ & $\begin{array}{r}-3.10 \\
-1.29 \\
-0.126\end{array}$ & $\begin{array}{r}-0.984 \\
-0.29 \\
-0.033\end{array}$ & $\begin{array}{r}-0.0326 \\
-1.40 \\
-0.150\end{array}$ & $\begin{array}{r}-0.133 \\
-1.71 \\
-\mathbf{0 . 6 1 3}\end{array}$ & $\begin{array}{r}-0.208 \\
-1.69 \\
-0.719\end{array}$ \\
\hline $\begin{array}{l}\text { Tariff Index of all } \\
\text { trading partners, } \\
\text { weighted by exports }\end{array}$ & & & & & $\begin{array}{r}0.223 \\
2.48 \\
0.242\end{array}$ & $\begin{array}{r}0.0383 \\
0.23 \\
\mathbf{0 . 0 4 1}\end{array}$ & $\begin{array}{r}-0.465 \\
-1.61 \\
-0.440\end{array}$ \\
\hline $\begin{array}{l}\text { (Tariff Rate) } x \\
\text { (Tariff Index of } \\
\text { Trading Partners) }\end{array}$ & & & & & & $\begin{array}{r}1.36 \\
1.35 \\
\mathbf{0 . 5 3 1}\end{array}$ & $\begin{array}{r}3.27 \\
1.61 \\
0.871\end{array}$ \\
\hline SEC70 & & & & $\begin{array}{r}0.0266 \\
1.55 \\
0.186\end{array}$ & & & $\begin{array}{r}0.000321 \\
1.95 \\
0.233\end{array}$ \\
\hline PRI70 & & & & $\begin{array}{r}0.00632 \\
0.67 \\
0.072\end{array}$ & & & $\begin{array}{r}0.000130 \\
1.35 \\
\mathbf{0 . 1 5 3}\end{array}$ \\
\hline GVXDXE & & & $\begin{array}{r}-9.05 \\
-3.40 \\
-0.310\end{array}$ & $\begin{array}{r}-7.87 \\
-2.61 \\
-0.277\end{array}$ & & & $\begin{array}{r}-0.0947 \\
-3.01 \\
-0.315\end{array}$ \\
\hline REVCOUP & & & $\begin{array}{r}-0.885 \\
-1.27 \\
-0.105\end{array}$ & $\begin{array}{r}-0.430 \\
-0.56 \\
-0.051\end{array}$ & & & $\begin{array}{r}-0.000754 \\
-0.10 \\
-0.010\end{array}$ \\
\hline ASSASSP & & & $\begin{array}{r}-2.02 \\
-1.44 \\
-0.110\end{array}$ & $\begin{array}{r}-2.30 \\
-1.61 \\
-\mathbf{0 . 1 3 5}\end{array}$ & & & $\begin{array}{r}-0.0201 \\
-1.49 \\
-0.126\end{array}$ \\
\hline PPI70DEV & & & $\begin{array}{r}-0.977 \\
-2.50 \\
-0.212\end{array}$ & $\begin{array}{r}-1.01 \\
-2.19 \\
-0.192\end{array}$ & & & $\begin{array}{r}-0.0103 \\
-2.30 \\
-0.209\end{array}$ \\
\hline INV7089 & & & $\begin{array}{r}7.94 \\
2.55 \\
0.340\end{array}$ & $\begin{array}{r}9.80 \\
2.86 \\
0.397\end{array}$ & & & $\begin{array}{r}0.0680 \\
2.01 \\
0.289\end{array}$ \\
\hline POP60LAND & & & $\begin{array}{r}0.00244 \\
2.97 \\
\mathbf{0 . 2 2 6}\end{array}$ & $\begin{array}{r}0.00231 \\
2.77 \\
0.231\end{array}$ & & & $\begin{array}{r}0.0000317 \\
3.71 \\
\mathbf{0 . 3 3 6}\end{array}$ \\
\hline POL & & & $\begin{array}{r}-0.989 \\
-2.66 \\
-0.228\end{array}$ & $\begin{array}{r}-1.11 \\
-2.32 \\
-0.236\end{array}$ & & & $\begin{array}{r}-0.00554 \\
-1.17 \\
-0.125\end{array}$ \\
\hline Constant & $\begin{array}{r}0.0201 \\
6.01\end{array}$ & $\begin{array}{r}0.00590 \\
0.32\end{array}$ & $\begin{array}{l}10.1 \\
4.69\end{array}$ & $\begin{array}{l}10.4 \\
3.88\end{array}$ & $\begin{array}{r}-0.0296 \\
-1.46\end{array}$ & $\begin{array}{r}-0.00972 \\
-0.39\end{array}$ & $\begin{array}{r}0.116 \\
3.56\end{array}$ \\
\hline $\begin{array}{l}\mathrm{N} \\
\mathrm{R}-\mathrm{Sq} \\
\text { Adj R-Sq }\end{array}$ & $\begin{array}{r}115 \\
0.039 \\
0.030\end{array}$ & $\begin{array}{r}114 \\
0.042 \\
0.025\end{array}$ & $\begin{array}{r}106 \\
0.511 \\
0.465\end{array}$ & $\begin{array}{r}87 \\
0.562 \\
0.498\end{array}$ & $\begin{array}{r}108 \\
0.115 \\
0.089\end{array}$ & $\begin{array}{r}108 \\
0.130 \\
0.096\end{array}$ & $\begin{array}{r}82 \\
0.604 \\
0.529\end{array}$ \\
\hline
\end{tabular}


Figure 4: Collinearity between Tariffs and Key Regressors of the Sachs and Warner Framework
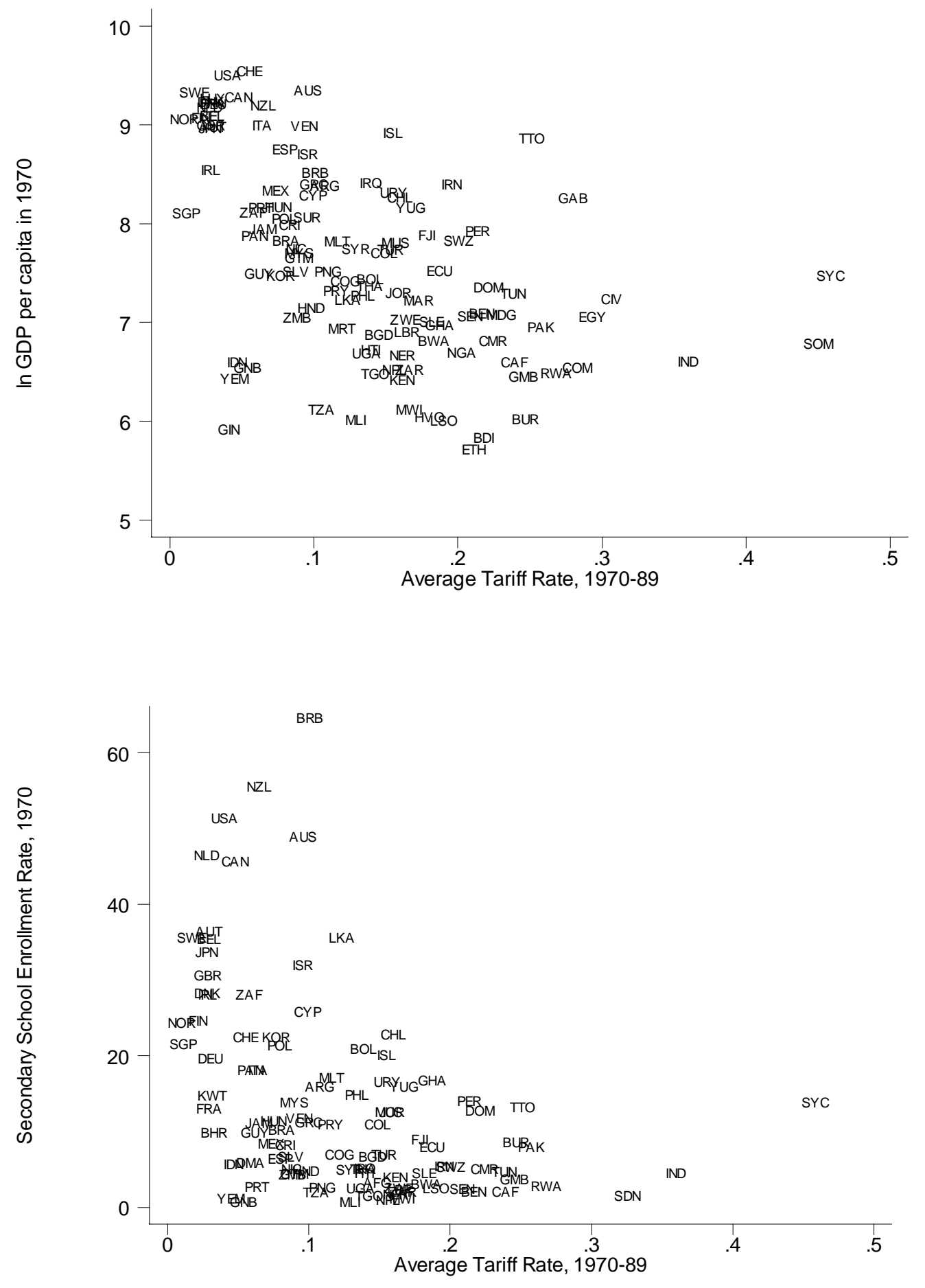


\section{Table 10: A New Specification for a Longer Post-War Period}

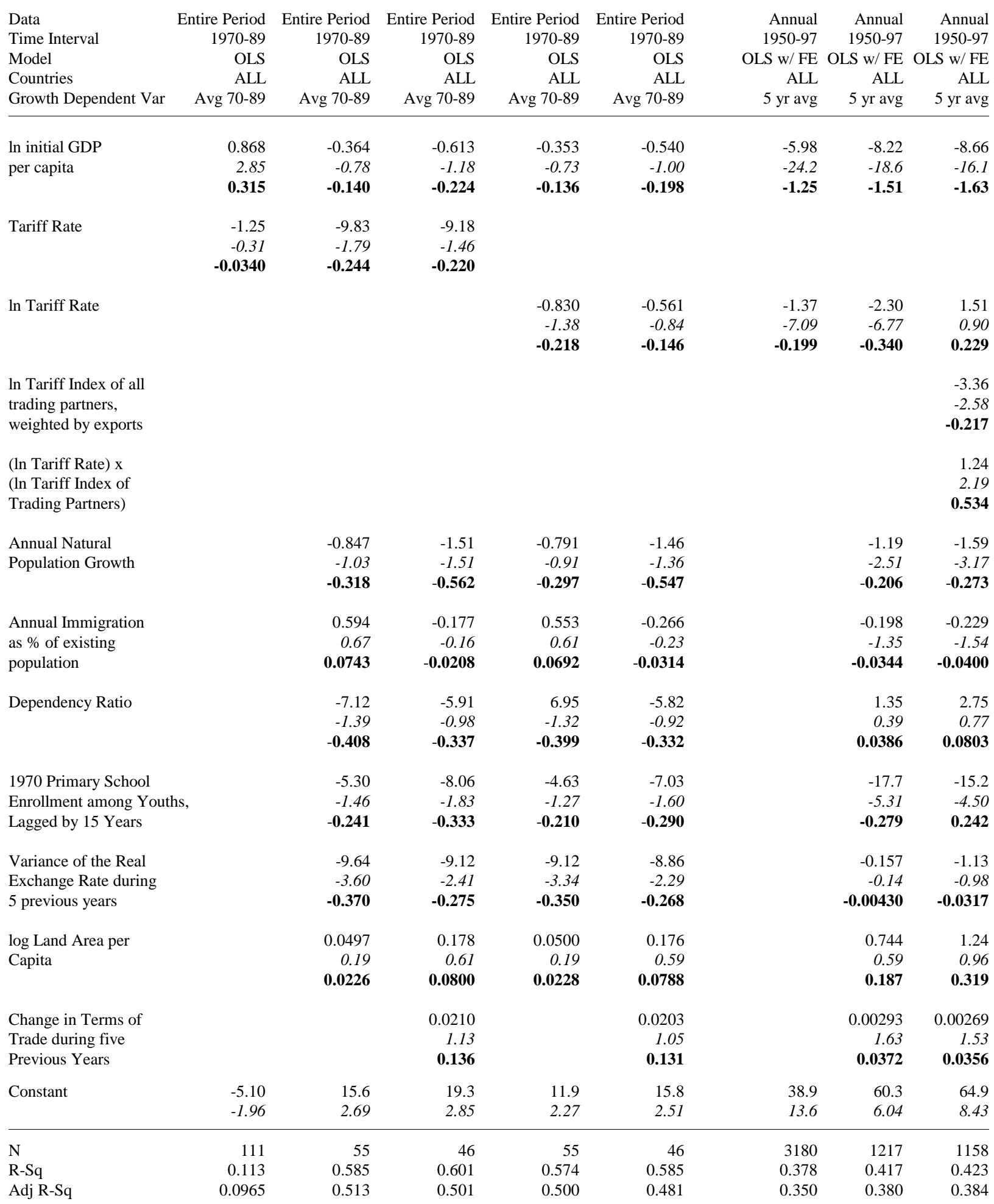

t-statistics are in italics, beta coefficients in boldface. 


\section{Table 11: What Changed after 1950?}

Dependent variable: Average annual growth in real GDP per capita during 5 years following the year in question

\begin{tabular}{|c|c|c|c|c|c|}
\hline Data & Annual & Annual & Annual & Annual & Annual \\
\hline Time Interval & $1950-97$ & $1950-97$ & $1950-97$ & $1970-89$ & $1950-97$ \\
\hline Model & OLS w/ FE & OLS w/ FE & OLS w/ FE & OLS w/ FE & OLS w/ FE \\
\hline Countries & ALL & ALL & ALL & ALL & Original 35 \\
\hline \multirow{3}{*}{ In GDP per capita } & -5.34 & -6.25 & -5.80 & -10.7 & -7.68 \\
\hline & -17.6 & -20.9 & -18.5 & -19.2 & -18.2 \\
\hline & -1.08 & -1.29 & -1.17 & -1.96 & -1.74 \\
\hline \multirow[t]{3}{*}{ In Tariff Rate } & -1.64 & 4.14 & 3.35 & 4.81 & 3.73 \\
\hline & -8.41 & 4.13 & 2.78 & 2.28 & 2.46 \\
\hline & -0.227 & 0.585 & 0.464 & 0.586 & 0.619 \\
\hline ln Tariff Index of all & 0.712 & -3.34 & -2.24 & 0.246 & -6.70 \\
\hline trading partners, & 1.89 & -3.90 & -2.15 & 0.12 & -5.32 \\
\hline weighted by exports & 0.0442 & -0.220 & -0.139 & 0.0125 & -0.446 \\
\hline (ln Tariff Rate) $\mathrm{x}$ & & 1.95 & 1.43 & 1.56 & 1.79 \\
\hline (ln Tariff Index of & & 5.76 & 3.54 & 2.02 & 3.31 \\
\hline Trading Partners) & & 0.803 & 0.573 & 0.571 & 0.822 \\
\hline Average annual GDP growth & 0.651 & & 1.09 & 0.913 & 1.06 \\
\hline between 1970 and 1989 & 23.5 & & 15.1 & 10.9 & 13.0 \\
\hline among trading partners & 0.392 & & 0.654 & 0.550 & 0.659 \\
\hline (ln Tariff Rate) $\mathrm{x}$ & & & -0.191 & -0.155 & -0.166 \\
\hline (GDP growth among & & & -6.71 & -4.62 & -4.28 \\
\hline Trading Partners) & & & -0.317 & -0.242 & -0.260 \\
\hline Weighted Average Effective & -0.00000599 & & -0.000513 & -0.00193 & 0.000439 \\
\hline \multirow[t]{2}{*}{ Distance to Trading Partners } & -0.03 & & -1.46 & -3.02 & 1.00 \\
\hline & -0.00167 & & -0.143 & -0.434 & 0.177 \\
\hline (ln Tariff Rate) $\mathrm{x}$ & & & 0.000224 & 0.000668 & 0.000155 \\
\hline (Weighted Average Effective & & & 2.08 & 3.19 & 1.25 \\
\hline Distance to Trading Partners) & & & 0.184 & 0.450 & 0.180 \\
\hline \multirow[t]{3}{*}{ OPEN } & 2.35 & & 4.70 & 5.07 & 2.23 \\
\hline & 7.52 & & 4.34 & 2.66 & 1.47 \\
\hline & 0.183 & & 0.366 & 0.343 & 0.205 \\
\hline \multirow[t]{3}{*}{ (ln Tariff Rate) x OPEN } & & & -1.03 & -1.07 & 0.196 \\
\hline & & & -2.47 & -1.49 & 0.33 \\
\hline & & & -0.179 & -0.144 & 0.0377 \\
\hline Weighted average of & 3.35 & & 4.36 & 14.0 & 5.76 \\
\hline \multirow[t]{2}{*}{ OPEN among Trading Parnters } & 5.78 & & 2.24 & 2.13 & 2.28 \\
\hline & 0.116 & & 0.151 & 0.281 & 0.240 \\
\hline (ln Tariff Rate) $x$ & & & -0.517 & -3.94 & -0.222 \\
\hline (Weighted average of & & & -0.7 & -1.52 & -0.22 \\
\hline OPEN among Trading Parnters) & & & -0.0708 & -0.437 & -0.0338 \\
\hline \multirow[t]{2}{*}{ Constant } & 51.4 & 29.5 & 44.3 & 68.0 & 41.6 \\
\hline & 12.2 & 8.49 & 9.3 & 8.93 & 8.24 \\
\hline $\mathrm{N}$ & 2477 & 2849 & 2477 & 1456 & 1062 \\
\hline $\mathrm{R}-\mathrm{Sq}$ & 0.535 & 0.393 & 0.551 & 0.634 & 0.572 \\
\hline Adj R-Sq & 0.515 & 0.365 & 0.531 & 0.605 & 0.554 \\
\hline
\end{tabular}

t-statistics are in italics, beta coefficients in boldface. 


\section{Data Appendix}

\section{PART I: BEFORE 1950}

Data for most variables for the period 1865-1913 come from Michael A. Clemens and Jeffrey G. Williamson, "Where did British Foreign Capital Go? NBER Working Paper 8028, National Bureau of Economic Research, Cambridge, Massachusetts (December 2000), which has a comprehensive appendix describing sources and methods. What follows dwells on 1914-1940 and on variables either missing from Clemens and Williamson or having been replaced by another source.

A number of sources are used frequently. They are: Arthur S. Banks, Cross-National Time Series, 1815-1973, [Computer File], ICPSR ed. (Ann Arbor, Michigan: Inter-University Consortium for Political and Social Research, 1976); Brian R. Mitchell, International Historical Statistics, Europe, 1750-1988 (New York: Stockton Press, 1992); Brian R. Mitchell, International Historical Statistics: The Americas, 1750-1988 (New York: Stockton Press, 1993); Brian R. Mitchell, International Historical Statistics: Africa, Asia \& Oceania, 1750-1993 (New York: Stockton Press, 1998).

\section{Average Tariff Rates: Import Duties over Imports}

Average tariff rates are calculated as the total revenue from import duties divided by the value of total imports in the same year. In some cases, the sources used do not distinguish between import and export duties, and report total customs duties only. Total customs duties are used in the calculation of average tariff rates (instead of import duties) for countries where the value of export duties has historically been an insignificant share of total customs duties. Sometimes, the value of import duties collected is reported for fiscal years, while import data generally refer to calendar years. While making a consistent effort to compare calendar year duties to calendar year imports, in cases where calendar year duties figures are unavailable, fiscal year duties are divided by calendar year imports to calculate average tariff. (In these instances, fiscal year import duties are assumed to belong to the calendar year in which most of the fiscal year falls).

Argentina: Average tariff figures for 1914-1930 are taken from Rosemary Thorp, "Economy, 1914-29," in Leslie Bethel (ed), Latin America: Economics and Society 1870-1930 (Cambridge: Cambridge University Press, 1989), p. 77, Diagram: "Tariffs as a percentage of import value, 1910-30". Figures for 1931-1937 come from Memoria de la Contaduria General de la Nacion, Volume 1 (Buenos Aires: Ministerio de Hacienda, various issues), 1931: p. 43, 1932: p. 115, 1934: p. 137, 1935: p. 159, 
1937: p. 177. Import duties for 1933 and 1936 and import figures for 1931-1937 are taken from $E l$ Comercio Exterior Argentino (Buenos Aires: various issues), 1933: p. 57, 1937: p. 61. Data for 1938-40 are from the United Nations Statistical Yearbook (Statistical Office of the United Nations, Department of Economic Affairs, New York, 1951), with imports on pp. 364-88, and customs duties on pp. 474-520. The yearbook asserts that "wherever the distinction is of quantitative importance, customs duties are subdivided into import and export duties" (p. 472).

Australia: Customs import duties and total imports are reported in the Official Year Book of the Commonwealth of Australia (Canberra: Commonwealth Bureau of Census and Statistics, Government Printer, various issues), 1915: p. 567, 1916: p. 595, 1917: p. 591, 1918: p. 616, 1919: p. 596, 1920: p. 616, 1921: p. 533, 1922: p. 502, 1927: p. 216 and 352, 1929: p. 227 and 350, 1933: p. 258, 1937: p. 520, 1941: p. 678. Import duties after 1930 include the so-called "primage duty" collected on Australian imports. Average tariff rates used in Clemens and Williamson (2000) were replaced for 1901-1913 with annual figures from Mitchell (1998).

Austria: Figures for 1922-1937 are taken from Mitchell (1992).

Brazil: Figures for 1914-1930 come from Bethel (1989), p. 77 (Diagram: "Tariffs as a percentage of import value, 1910-30"). For 1931-1936, import duties (“direitos de importacao para consumo") are taken from Contadoria Central da Republica, Balanco Geral da Uniao, 1936 (Imprensa Nacional, Rio de Janeiro, 1937), p. 136, while the value of total imports are from Comercio Exterior do Brazil, 1933-37 (Rio de Janeiro: Servico de Estadistica Economica E Financeira do Tresouro Nacional, Ministerio da Fazenda), p. 3. The ratio of "import taxes" and imports for 1937-1940 is calculated from A. K. Ludwig, Brazil: A Handbook of Historical Statistics (Boston: G.K. Hall \& Co., 1985), p. 314 (imports) and p. 354 (“import taxes").

Burma: Imports are reported annually and customs duties for every fifth year in Teruko Saito and Lee Kin Kiong, Statistics on the Burmese Economy (Singapore: Institute of Southeast Asian Studies, 1999), p. 175 (imports) and p. 201 (customs duties). Thus, average tariff rates are calculated for every fifth year and the missing years are interpolated geometrically.

Canada: Figures for 1867-1913 come from Mitchell (1993). For 1914-40, figures are taken from M. C. Urquhart and K. A. H. Buckley, Historical Statistics of Canada (Cambridge: Cambridge University Press, 1965), p. 173 (imports) and pp. 197-8 (“customs import duties”).

Ceylon: Figures for 1925-1940 come from Thirty Years of Trade Statistics of Ceylon (1925-54), (Colombo: Department of Commerce, Part 1, 1955), p. 1 ("merchandise imports") and p. 2 ("customs duties on imports"). Average tariff rates for 1921 and 1922 are calculated using the Annual General 
Report (Colombo: Government Record Office, various issues), 1922: pp. 21-22 and 1923: p. 10.

According to the figures in the Annual General Report, the value of export duties in Ceylon was almost exactly one third of the value of import duties in 1921-1923. Therefore, Ceylon's average tariff rate for 1914-1920 is estimated as follows: customs duties reported in Patrick Peebles, A Handbook of Historical Statistics (Boston: G.K. Hall \& Co., 1982), pp. 236-7, are multiplied by : to get an estimated value of import duties; then the estimated import duties are divided by the value of merchandise imports given in the Thirty Years of Trade Statistics of Ceylon (1955), p. 1.

Chile: Figures for 1914-1930 are taken from Markos J. Mamalakis, Historical Statistics of Chile (New York: Greenwood Press, 1989), vol. 6, p. 206. Figures for 1940-1950 are from Mamalakis, vol. 1, pp. $67-8$ (import duties) and p. 85 (imports). Figures for 1931-1939 are calculated as follows. Customs duties for 1930-1940 are from Mamalakis, vol. 6, pp. 506-7, while imports are found in Banks (1976) and converted to current pesos with the exchange rates in Bryan Taylor, Encyclopedia of Global Financial Markets, Seventh Edition (Los Angeles: Global Financial Data, 2000). According to Mamalakis, vol. 1, pp. 67-8, the value of export duties in Chile was consistently well under $1 \%$ of that of import duties, so using the sum of import and export duties for 1931-1939 in our calculations seems justified. Figures for 19311939 are estimated assuming that average tariff levels between 1930-1940 deviate from their trend (based on Mamalakis' figures for the years 1930 and 1940) in the same way (percentage-wise) as the tariff levels calculated from the Mamalakis customs duties and Banks imports deviate from their trend.

China: The treaties of Nanking (1843) and Tientsin (1858), as well as other similar treaties, limited the Chinese ad valorem tariff rate on imports from essentially all of Europe to 5\%. However, the treaties (and their revisions in 1870, 1902, 1917, and 1922) did not set ad valorem tariffs. Rather, they set specific nominal duties that, although initially equivalent to a $5 \%$ ad valorem tariff, rapidly declined in effective value as prices rose (C. F. Remer, The Foreign Trade of China (Shanghai: The Commercial Press Ltd., 1926), pp. 171-81). "The average effective rates were often below three percent and were never above four percent even in the years immediately following the revisions" (Yu-Kwei Cheng, Foreign Trade and Industrial Development of China (Seattle, Wash.: The University Press, 1956, pp. 8-13). For this reason it is assumed that import-duties-over-imports for China started at $4 \%$ in each year and declined at a constant rate to $2.5 \%$ in the year immediately preceding the next revision." (Clemens and Williamson 2000). Due to China's joining World War I, one such tariff revision took place in 1918. "But that revision proved inadequate since the yield at the time of the Washington Conference of 1921-1922 was estimated at only about 3 per cent. The Conference agreed to immediate revision to an effective 5 per cent" (Arthur N. Young, China's Nation-Building Effort, 1927-37 (Stanford, Cal.: Hoover Institution Press, 1971), p. 18). 
Finally, through negotiations the Nationalist government obtained tariff autonomy by 1929, which changed Chinese tariffs greatly. Young (1971) reports imports (pp. 492-3) and import duties (p. 52) for the period 1927-1937. The average tariff rates take account of Manchuria's foreign trade until 1931.

Colombia: Figures for 1924-40 are taken from the Anuario General de Estadistica (Bogata: Imprenta Nacional, various issues), which report customs duties (impuestos aduanas y recargos, 1935: pp. 296-7, 1951-1952: p. 281) and imports (1929: p. 364, 1935: p. 202, 1951-1952: p. 173).

Cuba: Figures for 1928-40 are taken from S. Schroeder, Cuba: A Handbook of Historical Statistics (Boston: G.K. Hall \& Co., 1982), p. 470.

Denmark: Figures for 1865-1913 come from Mitchell (1992). Figures for 1914-40 are taken from Hans Chr. Johansen, Dansk Historisk Statistik (Danish Historical Statistics), 1814-1980 (Copenhagen: Gyldendal, 1985), where total merchandise imports ("samlet vareindforsel”, pp. 196-7) and customs duties (“told", pp. 327 and 330) are reported.

Egypt: Figures for 1884-1935 are taken from the Annual Statement of the Foreign Trade of Egypt (Cairo: Statistical Department, Ministry of Finance, 1935), where "duty collected on imports" (of merchandise) is given on p. 6. Figures for 1938-1940 are from the United Nations Statistical Yearbook (1951). Figures for the period 1936-1937 are obtained through geometric interpolation.

France: Figures for 1865-1913 are from Mitchell (1992). Figures for 1914-1940 are taken from the Annauire Statistique, (Paris: Ministre des Finances et de Affaires Economiques, Impremerie Nationale, 1951), which reports total imports (pp. 190-1) and import duties (“droits d'importation”, p. 321).

Germany: Figures for 1880-1940 come from Mitchell (1992). Nonetheless, the following sources were also used to convince ourselves of the validity of the Mitchell figures: Deutsche Wirtschaftskunde (Berlin: Statistischen Reichsamt, Verlag von Reimer, Hobbing, 1933), pp. 119, 316, 336; Otto Nathan, The Nazi Economic System (Durham, North Carolina: Duke University Press, 1944), p. 320; Statistisches Jahresbuch für das Deutsche Reich (Berlin: Statistisches Reichsamt, various issues). Since the fragmented data in these sources on imports ("Einfuhr") and customs import duties ("Zölle" or "Zollerträge") match the figures in Mitchell (1992), the latter was used 1880-1940 for continuity.

Greece: Figures for 1911-1939 are taken from Statistique du Commerce de La Grece avec Les Pays Etranges, Volume I. (Athens: Impremerie Nationale, 1939), which gives imports (p. 4) and import duties (“droits d'importacion," p. 31).

India: Figures for 1910-1934 come from the Statistical Abstract of British India (London: His Majesty's Stationery Office, various issues), 1910-1920: pp. 62 and 152-3, 1920-1930: pp. 212-4 and 5345, 1926-1936: pp. 404-6 and 824-5. In this source, duties on imports by sea and total imports by sea are 
reported. The use of sea trade data to calculate average tariff levels seems justified given that customs revenues from land trade represented only about $0.5 \%$ of the customs duties on sea trade, and land imports were well under 10\% of sea-borne imports. Figures for 1935-1940 are from the Review of the Trade of India (Delhi: Department of Commercial Intelligence and Statistics, various issues), 1936-1937: pp. 32 and 263, 1937-1938: pp. 78 and 277, 1940-1941: pp. 101 and 249.

Indonesia: Figures for 1914-1939 are from W. L. Korthals Altes, Changing Economy in Indonesia: Volume 12a, General Trade Statistics 1822-1940, (Amsterdam: Royal Tropical Institute, 1991), pp. 54-6 (imports) and pp. 187-8 (import duties). Figures for 1940 are taken from the Statistical Pocket Book of Indonesia (Jakarta: Biro Pusat Statistik, 1957), p. 99 (imports) and p. 173 (import duties).

Italy: Figures for 1865-1913 are from Mitchell (1992). For 1914-1940, the data come from Thelma Liesner, One Hundred Years of Economic Statistics (New York: Facts on File, 1989), pp. 244-7.

Japan: Figures for 1865-1891 are from Mitchell (1998). Figures for 1892-1940 are taken from Japan Statistical Yearbook (Tokyo: Sorifu, Tokeikyoku, 1949), p. 471. Figures for 1866, and 1893-1896 are obtained through geometric interpolation.

Mexico: Figures for 1925-1937 come from the Anuario Estadistico (Mexico D. F.: Estados Unidos Mexicanos Secretario de la Economia Nacional Direccion General de Estadistica, various issues), reporting Mexican import duties (“impuestos a la importation,” 1930: p. 517, 1938: pp. 280-1, 1940: p. 741) and imports (1938: p. 247, 1940: p. 654). Figures for 1938-1940 are from the United Nations Statistical Yearbook (1951). Figures for the extended civil war period, 1913-1924, are estimated through geometric interpolation.

New Zealand: Figures are taken from the Official Year Book of New Zealand (Wellington: Government Printer, various issues), including 1894: p. 132 and endsheet, 1928: p. 341, 1932: p. 281, 1935: p. 233, 1938: p. 270, 1941: p. 249. Figures for 1865-1885 were estimated by assuming that tariff revenue represented the same average fraction of total tax revenue during 1865-1885 as it did 1886-1892 (i.e. roughly $70 \%$ ). The assumption is justified by the facts that a) this fraction was essentially constant on the period 1886-1892, and that b) this fraction back in 1851-1852 was also roughly $70 \%$ (endsheet of the 1894 edition of the Official Year Book has figures for 1851-1852).

Norway: Figures for 1865-1940 are from Mitchell (1992). The Historisk Statistikk (Oslo: Central Bureau of Statistics of Norway, 1978), pp. 261 and 446, was also used to check the validity of Mitchell's data.

Peru: Figures for 1914-1930 come from Bethel (1989), p. 77 (Diagram: "Tariffs as a percentage of import value, 1910-30"). Figures for 1931-37 are taken from the Extracto Estadistico del Peru (Lima: 
Preparado por la Direccion Nacional de Estadistica, 1938) reporting customs duties ("impuestas aduanas," p. 402) and total imports (p. 212). Data for 1938-40 are from the United Nations Statistical Yearbook (1951).

The Philippines: Figures for 1914-1940 come from the Annual Report of the Insular Collector of Customs (Manila: Bureau of Printing, 1937 and 1940), where import duties (1940: pp. 359-60) and imports (1937: pp. 66-7, 1940: p. 15) are presented.

Portugal: Average tariff levels are taken from Joao Luis Cesar das Neves, The Portuguese Economy: A Picture in Figures (Lisbon: Universidade Catolica Editora, 1994). The graph on p. 149 illustrates "Import Tax/Import" values for Portugal for the period 1836-1990.

Russia: Customs revenue to the central government of the Soviet Union and total imports from all international borders, 1924-28, are taken from the Statisticheskii Spravochnik SSSR 1928 (USSR Statistical Handbook 1928), Soiuz SSR TSentral'noe Statisticheskoe Upravlenie (USSR Central Statistical Agency), Moscow, 1929, pp 570, 713.

Yugoslavia (Serbia): Tariff figures are taken from W. S. Woytinsky and E. S. Woytinsky, World Commerce and Governments - Trends and Outlook (New York: The Twentieth Century Fund, 1955), p. 277, for benchmark years between 1913-1931. However, it has been noted that the average tariff levels in this source most likely refer to import-duties-over-dutiable-imports ratios, and thus are consistently higher than what other sources suggest. Therefore, Yugoslav tariff rates given in Woytinsky and Woytinksy (1955) have been altered: the benchmark values were converted to import-duties-over-total-imports estimates. The sum of tariff levels for Austria, France, Germany, Italy, Spain, and Sweden given in Woytinksy and Woytinsky (1955) in each benchmark year was divided by the sum of tariff levels for the same countries and years found in other sources (cited in this Data Appendix for each of the countries). Then, the Yugoslav tariff rates reported in Woytinksy and Woytinsky (1955) were divided by this ratio, in order to estimate Yugoslav import-duties-over-total-imports. Missing years have been geometrically interpolated. Also, it has been noted that the Serbian tariff level estimates used in Clemens and Williamson (2000) also refer to import-duties-over-dutiable-imports. Therefore, the Clemens and Williamson Serbian tariff figures for 1865-1913 were linked to the tariff levels calculated above for 1913-1931, yielding an estimate for Serbian import-duties-over-total-imports ratios for 1865-1913.

Spain: Figures for 1865-1940 come from two sources: imports are taken from L. Prados de la Escosura, El Progreso economico de Espana, 1850-2000 (Madrid: 2002), while "tariff revenue" is taken from F. Comin, Fuentes cuantitativas para el estudio del sector publico en Espana. (Madrid: 1985).

Sweden: Average tariff figures for 1865-1910 are from Mitchell (1992). Figures for 1911-1940 are 
taken from Handel (Stockholm: Sveriges Officiella Statistik, various issues), where customs duties as a percentage of imports (“Tulluppbörd i \% av införseln") are given in various issues (1917: p. 34, 1926: p. 28, 1936: p. 32, 1945: p. 37, 1951: p. 34).

Thailand: Figures for 1914-1940 are taken from Constance M. Wilson, Thailand: A Handbook of Historical Statistics, (Boston: G.K. Hall \& Co., 1983), pp. 210-1 (imports) and pp. 242-4 (customs duties).

Turkey: Figures for 1923-1940 come from the Annuaire Statistique (Ankara: Republique Turque, Office Central De Statistique, various issues), which report imports (1928: pp. 103-6, 1932-1933: p. 250, 1938-1939: p. 231, 1948: p. 396, 1951: p. 357) and import taxes ("taxes douanieres," i.e. "gümrük resmi," 1928: pp. 156-7, 1930: p. 310, 1932-1933: p. 302, 1938-1939: pp. 276-7, 1942-1945: p. 385, 1948: p. 434, 1950: p. 245, 1951: p. 324).

United Kingdom: Figures for 1865-1940 are taken from Brian R. Mitchell, British Historical Statistics (Cambridge: Cambridge University Press, 1988), where imports (p. 453) and customs revenue (pp. 582-4) are reported annually.

United States: Figures for 1865-1940 come from Woytinsky and Woytinsky (1955), pp. 263-4. The reported data are "duties as percentage of total imports" (emphasis added). Thus, the Woytinsky and Woytinsky US series does not have the upward bias mentioned previously for the case of Yugoslavia. Some missing years falling in the period 1865-1910 are geometrically interpolated.

Uruguay: Figures for 1913-1940 are taken from Anuario Estadistico (Montevideo: Ministerio de Hacienda, Direccion General de Estadistica y Censos, various issues), where import duties ("derechos de aduana s. importacion") and imports are reported annually. Tariff figures for two missing years, 1923 and 1939, are estimated by geometric interpolation.

\section{Population}

For the entire period under observation, annual estimates of the population (in thousands) of Argentina, Australia, Austria, Brazil, Canada, Chile, China, Colombia, Cuba, Denmark, France, Germany, Greece, Italy, Mexico, New Zealand, Norway, Peru, Portugal, Russia, Spain, Sweden, Thailand, United Kingdom, Uruguay, USA, and Yugoslavia are given in Banks (1976). Missing war years 1914-1918 are derived by geometric interpolation.

Population for Ceylon (Sri Lanka) is taken from Mitchell (1998), while that for Burma, Egypt, India, Indonesia, Japan, Philippines, and Thailand are taken from Maddison (1995).

Population for Australia before 1901, Cuba before 1902, Germany before 1867, New Zealand before 1907, and Serbia before 1878 are not reported in Banks (1976). For these, the population figures in 
Clemens and Williamson (2000) are used, linked to the Banks figures. For Ceylon and India, the figures used in Clemens and Williamson for 1865-1913 are linked to the post-1914 series.

\section{GDP and GDP per Capita}

For most countries, gross domestic product per capita (in 1990 US dollars) is taken from Angus Maddison, Monitoring the World Economy 1820-1992 (Paris: Development Center of the Organization for Economic Cooperation and Development, 1995). Missing years are geometrically interpolated.

For five countries not reported in Maddison (1995)—Ceylon, Cuba, Egypt, Portugal and Uruguay, GDP per capita is calculated by dividing a country's income (in 1990 US dollars) by population in every year. Sources of the population data have been described above, and the sources of the income estimates follow.

GDP per capita for Ceylon in 1914 is benchmarked relative to India's in 1914 by the ratio (1.95) given in Burnham O. Campbell, "Development Trends: A Comparative Analysis of the Asian Experience," in Naohiro Ogawa et al., eds., Human Resources in Development Along the Asia-Pacific Rim (New York: Oxford University Press, 1993). The same ratio had declined to 1.52 by 1948 according to United Nations Statistical Yearbook 1949-50 (New York: 1950), pp. 21-2 and 406. In the intervening years, it is assumed that this ratio declined annually at a constant rate.

Cuba's Net National Product in current year pesos comes from Mitchell (1993). These NNP values are converted to 1990 US dollars with the help of the peso-dollar exchange rate given in Taylor (2000) and the American historical consumer price index given in John McCusker, How Much Is That in Real Money (Worcester, Mass.: American Antiquarian Society, 1992), pp. 330-2.

A trend for Egyptian GDP per capita is calculated with the help of benchmark values given in Maddison (1995). Annual GDP per capita estimates are then calculated under the assumption that Egypt deviated from the Maddison-estimated Egyptian benchmark trend in the same way (percentage-wise) as Turkey did from her GDP per capita trend (after the civil war).

Figures for Portugal come from das Neves (1994). The GDP figures given in both current and 1914 constant escudos are converted to 1990 US dollars using the escudo-dollar exchange rate given in Taylor (2000) and the American historical price index in McCusker (1992).

GDP for Uruguay is taken from Mitchell (1993) for the period 1935-1940. Annual GDP per capita estimates for 1914-1934 are calculated by assuming that Uruguay deviated from her GDP per capita trend (between the benchmark years of 1914, found in Clemens and Williamson (2000), and 1935, found in Mitchell) in the same way that Argentina did. 


\section{Share of Primary Product Exports in Total Exports}

This variable denotes the fraction of total export values consisting of "primary products" (defined below). Viewed as an indicator of the relative endowment of natural resources, it was made popular by Jeffrey Sachs and Andrew Warner, "Natural Resource Abundance and Economic Growth,” NBER Working Paper 5398, National Bureau of Economic Research, Cambridge, Mass. (December 1995). They defined "primary products" as those commodities falling into categories $0,1,2,3,4$, and 68 of the United Nations Standard International Trade Classification (SITC) Revision 1. These categories are, respectively: food and live animals, beverages and tobacco, crude materials excluding fuels, mineral fuels, animal or vegetable oils and fats, and non-ferrous metals. We use a slightly different definition of primary products, namely categories I, II, and III, of the Brussels 1913 Commodity Classification (recorded in Conference Internationale de Statistique Commerciale, Bruxelles, 1913: Documents et Proces-Verbaux, Establissements Generaux D'Imprimerie, Brussels, 1914). These categories are, respectively: live animals, food and drink, and raw materials or simply-prepared products. Thus, our definition of primary products includes all exports except categories IV (manufactured products) and V (money and specie). The only substantive differences between our definition of primary products and that of Sachs-Warner are that the former includes iron ore and excludes manufactured tobacco products like cigarettes and cigars.

Figures for the United States, Germany, France, Russia, Australia, Austria, Canada, Italy, Japan, Spain, Sweden, New Zealand, United Kingdom, and India come from the League of Nations, Industrialization and Foreign Trade (Geneva: Economic, Financial, and Transit Authority, 1945), pp. 15467.

The sources of the figures for the remaining countries are the following: Argentina, Direccion General de Estadistica de la Nacion, El Comercio Exterior Argentino (Buenos Aires: various issues), 1925: pp. 26-30 and 1936: pp. 61-70; Brazil, Ministerio da Fazenda, Comercio Exterior do Brasil (Rio de Janeiro: various issues), 1929: pp. 62-83 and 1933: pp. 74-95; Burma, Report on the Trade and Customs Administration of Burma, 1937-38, (Rangoon: Government Printing and Stationery, 1938), p. 18, and Teruko Saito and Lee Kin Kiong, Statistics on the Burmese Economy (Singapore: Institute of Southeast Asian Studies, 1999), p. 181; Ceylon, Thirty Years of Trade Statistics of Ceylon, 1925-1954, (Colombo: Department of Commerce, Government Press, 1955), pp. 29-33; Chile, Estadistica Chilena (Santiago: Direccion General de Estadistica, various issues), 1928: p. 40 and 1935: p. 17; China, Yu-Kwei Cheng, Foreign Trade and Industrial Development in China (Westport, Conn: Greenwood Press Publishers, 1956), p. 35. Articles labeled as "semi-manufactured products" by Cheng are assumed to be primary 
products; Colombia, Departamento de Contraloria, Anuario Estadistico de Comercio Exterior (Bogota: 1929), pp. 17-20 and Contraloria General de la Republica, Comercio Exterior de Colombia (Bogota: 1937), pp. 4-11; Cuba, Secretaria de Hacienda, Comercio Exterior (Havana: various issues), 1926: p. IX, and 1946: p. 11; Denmark, Danmarks Vareinforsel og - Udforsel, 1925 and 1935 (Copenhagen: Danmarks Statistik, Department of Statistics, 1926 and 1936), 1925: p. 8, 1935: p. 8; for Egypt and Indonesia, figures are obtained through geometrical interpolation between the benchmark value in 1914, given in Clemens and Williamson (2000), and the benchmark value in 1954, found in the United Nations Yearbook of International Trade Statistics 1955 (Statistical Office of the United Nations, Department of Economic and Social Affairs, New York, 1956). Interpolation over such a long period of time seems justified because for both countries in question, the figures for 1914 and 1954 are very similar; Greece, M. Dorizas, The Foreign Trade of Greece (Philadelphia: University of Pennsylvania PhD thesis, 1925), Appendix 2; Mexico, Anuario de 1930 (Mexico D. F.: Departamento de Estadistica Nacional, Tacubaya, 1932), p. 442 and Secretaria de la Economia Nacional, Anuario Estadistico de los Estados Unidos Mexicanos 1939 (Mexico D. F.: 1941), p. 578; Norway, figures are estimated using the following sources: Values of export of manufactured and primary products in 1913 are found in Norway Foreign Trade (Oslo: The Trade Intelligence Bureau of Norway, 1923), p. 11. An index of the exports of manufactures in 1913-1930 is given in Norwegian Trade Review (Oslo: A.S Norwegian Publications), March 1931, vol. 2, no. 3, p. 68. These two sources are combined to estimate the value of primary product exports. Primary product exports are then divided by the value of total exports, reported in Banks (1976); Peru, Ministerio de Hacienda y Comercio, Comercio Especial del Peru (Callao: Estadistica General de Aduanas, 1926), p. XXIV) and Anuario del Comercio Exterior del Peru (Callao: Departamento de Estadistica General de Aduanas, 1936), unnumbered page; Portugal, Ministerio das Financas, Anuario Estatistico de Portugal (Lisbon: various issues), 1926: p. 214 and 1936: p. 376; the Philippines, O. M. Butler, The Philippines Islands: A Commercial Survey (Washington, D. C.: U. S. Department of Commerce, Trade Promotion Series, vol. 52, 1927), p. 116; Thailand, Annual Statement of the Foreign Trade and Navigation of the Kingdom of Siam (Bangkok: Department of His Majesty's Customs, 1935-36), pp. 163-71; Turkey, U. S. Department of Commerce, Turkey, Commercial and Industrial Handbook (Washington, D. C.: Government Printing Office, 1926), p. 179; Uruguay, Anuario Estadistico de la Republica Oriental del Uruguay (Montevideo: Imprenta Nacional, Montevideo, various issues), 1927: p. 213 and 1936: p. 215; Yugoslavia, U. S. Department of Commerce, Kingdom of Serbs, Croats, and Slovenes (Yugoslavia), a Commercial and Industrial Handbook (Washington, D. C.: Government Printing Office, 1928), p. 225. For every country, missing values are estimated by geometric interpolation between the primary A-10 
product export fractions at benchmark years.

\section{Export Share}

Export Share is calculated as the ratio of exports to national income. GDP is used in the denominator, and its sources can be found above. Data for exports (in current US dollar equivalents) come from Banks (1976), except for Burma, Ceylon, Egypt, India, Indonesia, the Philippines, Portugal, and Uruguay. The export figures given in Banks in current US dollars are converted to 1990 US dollars using the American historical consumer price index in McCusker (1992). Export data for the years 1914-1918 are obtained by geometric interpolation. Dividing these interpolated export figures by GDP gives the openness ratios for the war-time years.

Export figures for Ceylon, Egypt, India, Indonesia, and the Philippines are found in Mitchell (1998). The export figures given in current national currency units in Mitchell are converted to 1990 US dollars using the exchange rates in Taylor (2000) and the American historical consumer price index in McCusker (1992). Once converted to 1990 US dollars, the export data for India, Indonesia, and the Philippines are divided by Maddison's (1995) GDP estimates to get the openness variable. The calculation of Ceylon, Egypt, and Uruguay's per capita GDP has already been described. Per capita GDP figures for these three countries were multiplied by their population estimates to get GDP. Exports were then divided by these GDP levels to get the openness ratio of Ceylon, Egypt, and Uruguay.

To calculate openness for Burma, we rely on Saito and Kiong (1999), who provide estimates of Burmese Net Domestic Product and exports in current rupees until 1938. For Portugal, export and GDP figures in current escudos are taken from das Neves (1994).

\section{Effective Distance from Trading Partners}

Effectuve Distance from trading partners is calculated as the product of two quantities. The first quantity is the average distance from the capital city of the country in question to the capital cities of its principal trading partners, weighted by the value of exports going to each of those partners in the year in question. Distances are taken from the Microsoft Excel Worksheet prepared by Howard Shatz's unpublished data (Cambridge: Harvard University Center for International Development, 1997), which gives them in miles between 254 (mainly capital) cities of the world using the great circle formula. The second quantity is an index of tramp shipping freight charges (per distance and weight) shown in Table VIII (p. 122) of L. Isserlis, “Tramp Shipping Cargoes, and Freights,” Journal of the Royal Statistical Society, 101, 1 (1938): pp. 53-146. Distance from the closest world export center is multiplied by this 
shipping freight index. Note that the Isserlis index only offers an estimate of changes in global transportation costs which is generic to the world as a whole. By using it, we only control for differences in transportation costs over time, not across space. The later are not yet available on the comprehensive scale that this data set demands.

\section{Energy Consumption per Capita}

As is common in historical studies with limited endowment data, energy consumption per capita is used as a proxy for capital-labor ratios. For most countries, energy consumption in kilograms of coal equivalent per capita from the year 1919 onwards is taken from Banks (1976).

Data for Burma, Ceylon, China, India, Indonesia, and Philippines come from the United Nations, World Energy Supplies in Selected Years, 1929-1950 (New York: Statistical Papers, Series J, no. 1, 1952), pp. 64-6, where per capita consumption of commercial uses of energy is reported in metric tons for benchmark years between 1929-1950. Figures for missing years between the benchmark values are obtained by geometric interpolation. Figures for 1914-1928 for these six countries only are estimated as a linear function of population, GDP per capita, openness, population growth, primary product exports as a fraction of total exports, primary school enrollment as a fraction of population below age 14, land area, and railroad mileage per capita. The prediction function is calibrated for each country using known energy consumption during 1929-1950, when it performs extremely well, and is assumed valid for 1914-1928 as well. The same prediction function was applied to Egypt in the absence of calibrating data, there being little reason to believe that Egyptian energy usage patterns during this period were radically different from peer countries.

\section{Infant Mortality}

Infant mortality denotes the number of deaths of infants under one year old per 1000 live births, and they are taken from the appropriate edition of Mitchell's International Historical Statistics (1992, 1993, 1998) for every country except six —Brazil, Burma, China, Indonesia, Thailand, and Turkey. Figures are collected for the entire period of 1865-1940, but for some countries data are not available all the way back to 1865. For the period 1921-1938, figures for Burma, Thailand, and Turkey come from the League of Nations, Statistical Year-Book of the League of Nations (Geneva: League of Nations Economic Intelligence Service, 1941). In case of Thailand, 1921-1935 data for the "straits settlements" (comprising roughly modern-day Malaysia) are used as a proxy; after 1936 unproxied Thai figures come from Wilson (1983), p. 46. For Turkey, the average of Greece, Yugoslavia and Egypt is used for benchmarks, and for 
the missing Turkish years in between those benchmarks, the trend for Egypt is assumed.

Figures for Brazil are taken from Ludwig (1985), p. 84. The unweighted average of the infant mortality rates of several urban counties is used to estimate Brazil's overall infant mortality rate.

Infant mortality rates for Peru come from Mitchell (1993) from 1940 onwards only. Before 1940, Peru is assumed to follow Colombia's trend.

Figures for China are estimated by India's infant mortality rates, while the infant mortality rates of the Philippines are used as a proxy for Indonesia.

\section{Inflation}

Inflation is calculated as the annual percentage change in the Consumer Price Index (CPI) of each country. The annual change in the CPI for most countries is given in Taylor (2000). Inflation figures are collected for the period 1865-1940. However, figures in Taylor's database do not reach back all the way to 1865 for every country.

Figures for Burma are estimated by using the Burmese cost of living index in the United Nations Statistical Yearbook 1949-50 (New York, 1950) p. 402 and the Indian CPI given in Taylor (2000).

Figures for the Philippines are estimated using the cost of living index given in the United Nations Statistical Yearbook 1949-50 (New York, 1950), p. 403 and the Yearbook of Philippine Statistics (Manila: Bureau of the Census and Statistics, Republic of the Philippines, 1947), p. 251; augmented by the cost of living trends for China, India, and Japan reported in the United Nations Statistical Yearbook 194950 , and by the retail and wholesale price trends for China, India, Indonesia, and Japan in the Statistical Year-Book of the League of Nations (Geneva: various issues), 1931/32: pp. 312-21 and 1938/39: pp. 2316.

Cuban inflation is estimated using the following pieces of evidence: the index of the cost of food in Cuba given in the Anuario Estadistico de Cuba de 1952 (Havana: Ministerio de Hacienda, Republica de Cuba), p 285; the Cuban cost of living index from the United Nations Statistical Yearbook 1949-50, p. 401; and annual changes in the CPIs of Argentina, Brazil, Chile, Colombia, Mexico, and Peru taken from Taylor (2000).

Inflation for Ceylon are estimated using the export and import price indices, the terms of trade index, and the working class cost of living index for Ceylon given in Thirty Years Trade Statistics of Ceylon (1925-1954), Part IV (Colombo: Government Press, 1957), p.1901.

Inflation for Thailand is calculated as the annual percentage change in the wholesale food price index, taken from Wilson (1983), p. 322. 
Inflation for Indonesia is calculated from the Consumer Price Index given in Mitchell (1993).

Inflation for Portugal is estimated with the annual change of the GDP deflator given in das Neves (1994), pp. 193-7.

For Colombia, figures for 1917-1924 come from Mitchell (1993), while figures for the rest of the period are taken from Taylor (2000).

\section{Land-Labor Ratio}

The land-labor ratio is calculated by dividing total area of arable (food) crops in hectares by labor force.

Estimates for the sixteen countries consisting of Argentina, Australia, Canada, Uruguay, USA, UK, Denmark, Sweden, France, Germany, Spain, Egypt, Thailand, India, Burma, and Japan are taken from the database underlying the analysis in J. G. Williamson, "Land, Labor and Globalization in the PreIndustrial Third World, NBER Working Paper 7784, National Bureau of Economics Research, Cambridge, Mass. (July 2000) where they are described in an appendix. The method, however, is the same as that described below for the remaining 19 countries.

Estimates for the nineteen countries consisting of Austria, Brazil, Ceylon, Chile, China, Colombia, Cuba, Greece, Indonesia, Italy, Mexico, New Zealand, Norway, Peru, Philippines, Portugal, Turkey, USSR, and Yugoslavia were calculated in the following way: Total area of arable crops (in hectares) are taken from the appropriate edition of Mitchell's International Historical Statistics $(1992,1993,1998)$. The labor force is estimated by the population between the ages 15 and 64. The fraction of the population between ages 15 and 64 are calculated from Mitchell (1992, 1993, 1998), but provided for census years only. The fraction 15-64 was then multiplied by the total population in the census years to get benchmark estimates of the each country's labor force, and thus the land-labor ratio. Land-labor ratios for the missing years between the benchmarks are estimated by geometric interpolation.

\section{School Enrollment Rate}

Two variables are used to measure the primary school enrollment rates for those of school age. The first variable is primary school enrollment per capita. The second is the population share under the age of 14. Each variable is described in turn.

Per capita primary school enrollment rates for most countries are taken from Banks (1976), and war-time years (1914-1918) are geometrically interpolated.

Primary school enrollment for Burma, Ceylon, Egypt, India, Indonesia, and the Philippines are 
from Mitchell (1998). These figures are then divided by the size of the population of each country, in order to arrive at per capita school enrollment. Figures for Ceylon denote primary and secondary school enrollment per capita combined. (It is assumed that secondary enrollment is a tiny fraction of total school enrollment in Ceylon.)

Primary school enrollment figures for Australia are from Peter H. Lindert, "Democracy, Decentralization, and Mass Schooling Before 1914: Appendices," Working Paper 105, Agricultural History Center, University of California at Davis (2001), pp. 11-12. Missing years are geometrically interpolated.

Primary school enrollment rates for those of school age are calculated by dividing per capita primary enrollment rates by the fraction of the population under the age of 14 . The fraction of the population under the age of 14 is calculated from the appropriate editions of Mitchell $(1992,1993,1998)$, where the population distributions by age are provided for census years. The youth dependency ratios (i.e. fraction of the population under the age of 14) for missing years are obtained by geometric interpolation.

\section{Railroad Mileage}

Railroad mileage, defined as miles of line (public and private) rather than miles of track, is taken from Banks (1976), and war-time years (1914-1918) are geometrically interpolated.

\section{Land Area}

Land area, excluding non-contiguous colonies, and in thousands of square miles, is taken from Banks (1976). Where a country's borders were changed during World War I, we assume that the change took place in 1919. In the case of Australia, Burma, Ceylon, Cuba, Egypt, India, Indonesia, New Zealand, Philippines, and Serbia, where Banks (1976) does not report land area for the beginning of our observed period, land area is assumed to be unchanged going back to 1865 .

\section{Terms of Trade}

Terms of trade figures for 1870-1940 for Argentina, Australia, Burma, Canada, Denmark, Egypt, France, Germany, India, Japan, Spain, Sweden, Thailand, United Kingdom, Uruguay, and USA are taken from the database underlying Williamson (2000). However, these figures were converted from the base year 1911, to 1900 .

For countries not covered in Williamson, terms of trade figures for 1865-1914 are taken from Clemens and Williamson (2000). Missing years for Argentina, Burma, Germany, and Sweden are filled in 
from Clemens and Williamson as well.

\section{Exports to Main Trading Partners}

This variable denotes the value of exports (in current national currency units) to a country's main trading partners. Figures for every country are presented in the appropriate editions of Mitchell (1992, 1993, 1998).

\section{Trading partner tariffs and growth}

The index of tariffs in principal trading partners is calculated as the weighted average of own tariffs in the four or five countries to which the country in question exported the largest absolute value of goods (for three countries-Colombia, New Zealand, and the Philippines-only the top three trading partners are covered). The weights are the absolute value of exports that went to each of said partners. These partner export figures are taken from Mitchell op. cit. In all cases, the vast majority of each country's exports are accounted for by exports to these principal trading partners. The index of growth in principal trading partners is calculated in identical fashion.

\section{PART II: AFTER 1950}

\section{Import Duties over Imports}

After 1970, these are taken from the World Bank's World Development Indicators 2000 CDROM. Prior to 1970 and in cases of missing numbers for 1970-75 in the World Bank data, they are taken from the United Nations Statistical Yearbook, "Public Finance" and "External Trade" sections, 1951, 1957, 1963, 1967, 1973, and 1977, Statistical Office of the United Nations, Dept. of Economic and Social Affairs, New York. In all cases the United Nations data are collected until a sufficiently late year as to provide significant overlap with the World Bank numbers, to ensure that the two series matched up well at the interface. Since European Union tariffs are collected by a central authority, customs revenue to national governments trends quickly towards zero when countries join the EU. For this reason, the ratio of import duties to imports for the entire EU is applied to each member country starting from the year it joined the Union.

\section{Effective Distance}

Physical distance comes from Shatz op. cit., and is multiplied by an index of transportation costs 
to calculate "effective distance" exactly as described in the pre-1950 section. The index of transportation costs is calculated using data provided by David Hummels which are described in David Hummels 1999, "Have International Transportation Costs Declined?" M imeo, U niversity of Chicago (as of this writing he has relocated to Purdue U niversity). A worldwide index of transportation costs is constructed as a weighted average of Hummels' air and ocean shipping cost indices, weighted by the fraction of world trade going by each mode of transportation in each year.

\section{Openness}

The OPEN variable described in Jeffrey Sachs and Andrew Warner, 1995, "Economic Reform and the Process of Global Integration," Brookings Papers on Economic Activity, 1:1-118 is available on the website of Harvard University's Center for International Development, http://www.cid.harvard.edu/ciddata/ciddata.html. The other regressors used by Sachs and Warner have been posted by Robert Barro and Jong-Wha Lee on the website of the National Bureau of Economic Research, http://www.nber.org/pub/barro.lee.

\section{Trading Partners}

Exports from every country in the world to every other country in the world, 1950-1997, are taken from the Direction of Trade database published by the International Monetary Fund (IMF, Direction of Trade Statistics, 1948-1997, [C omputer File], ICPSR ed. (A nn A rbor, M ichigan: Inter-U niversity Consortium for Political and Social Research, 1998)). These export values, for each country in each year, are used as weights when calculating the average OPENness of trading partners, average effective distance to trading partners, average GDP growth among trading partners, and average trading partner tariffs.

\section{Other regressors}

Population, natural population growth and immigration figures are taken from the United Nations Demographic Yearbook, Historical Supplement 2000 on CD-ROM. Primary school enrollment, the fraction of the population below age 15, and the dependency ratio (the ratio of the population aged below 15 or above 64 to the population between the ages of 15 and 64) are taken from World Bank's World Development Indicators CD-ROM 2000. Real GDP per capita, real exchange rates and Terms of Trade are taken from the International Monetary Fund's International Financial Statistics CD-ROM 2000. Also used (see footnote 16) were the real GDP per capita figures of Summers and Heston (Penn World Tables v5.6, 2000, Center for International Comparisons, University of Pennsylvania, Philadelphia. Available at http://pwt.econ.upenn.edu). 